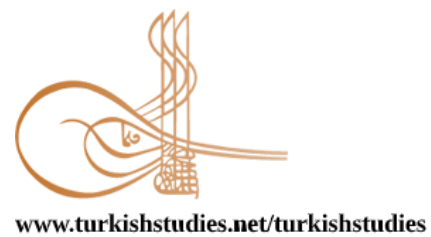

Turkish Studies

www.turkishstudies.net/turkishstudies

eISSN: 1308-2140

BALKAN

Sponsored by IBU

Research Article / Araștırma Makalesi

\title{
Paphlagonia Hadrianoupolis’i Geç Roma Villası'nda Yer Alan Duvar Resimlerinin Korunması Kapsamında Ön İnceleme Çalışmaları
}

\author{
Preliminary Investigations within the Conservation of Wall Paintings In the Late Roman Villa of \\ Paphlagonia Hadrianoupolis
}

Ezgin Yetiş* - Murat Eroğlu** - Kıymet Deniz ${ }^{* * *}-$ Yusuf Kağan Kadığlu****

\begin{abstract}
It consists of preliminary studies carried out the wall paintings found in the Late Roman Villa, Karabük Hadrianoupolis Ancient City. In the examination studies; the conservation status of the paintings, past restorations, humidity conditions, UV-light examinations, optical microscope images and analytical measurements of the samples taken from the paint and renders were evaluated. Then some suggestions were given about the conservation processes. There are wall paintings in the room of 3, 4 and 5 in the villa. Merely the protection cover of room-3 was removed and samples were taken. Thin-section petrography, crosssection optical microscope images, FTIR (Fourier Transform Infrared) Spectroscopy, XRF (X-Ray Fluorescence), XRD (X-ray diffraction) and CRS (Confical Raman Spectroscopy) were examined. Lime, sulfate salts and acrylic resins were determined in IR spectrum and acrilic resins may be used in past restorations. Mortars with medium hydraulic and natural cement renders/mortars in XRF, calcite crystal structures in XRD; pigments based on carbon and siderite $\left(\mathrm{FeCO}_{3}\right)$ in $\mathrm{CRS}$ were identified. Broken bricks (cocciopesto) and natural fibres mortars are observed in thin-section petrography. Moreover, the images in cross-section optical microscope examinations indicate fresco techniques. In the 5-day preliminary study, which started with the removal of the protective cover of the wall paintings and completed with a new cover, the moisture changes of the plaster was determined and $80 \%$ relative humidity were measured. Humidity
\end{abstract}

\footnotetext{
* Dr. Öğr. Üyesi, Kastamonu Üniversitesi, Güzel Sanatlar ve Tasarım Fakültesi, Sanat Eserleri Konservasyonu ve Restorasyonu Bölümü

Asst. Prof., Kastamonu University, Fine Arts and Design Faculty, Conservation and Restoration of Artworks

ORCID 0000-0003-3375-7432

ezginyetis@hotmail.com

** Dr. Öğr. Üyesi, Kastamonu Üniversitesi, Fen Edebiyat Fakültesi, Arkeoloji Bölümü

Asst. Prof., Kastamonu University, Faculty of Arts and Sciences, Archaeology

ORCID 0000-0001-8807-3906

meroglu@kastamonu.edu.tr

*** Dr. Öğr. Üyesi, Ankara Üniversitesi, Mühendislik Fakültesi, Jeoloji Mühendisliği

Asst. Prof., Ankara University, Faculty of Engineering, Geological Engineering

ORCID 0000-0003-3208-1354

kdeniz@eng.ankara.edu.tr

***** Prof. Dr., Ankara Üniversitesi, Mühendislik Fakültesi, Jeoloji Mühendisliği

Prof. Dr., Ankara University, Faculty of Engineering, Geological Engineering

ORCID 0000-0002-7894-2220

kadi@ankara.edu.tr

Cite as/ Atıf: Yetiş, E., Eroğlu, M., Deniz, K. \& Kadıŏlu, Y.K. (2021). Paphlagonia Hadrianoupolis’i Geç Roma Villası'nda yer alan duvar resimlerinin korunması kapsamında ön inceleme çalışmaları. Turkish Studies, 16(7), 355378. https://dx.doi.org/10.7827/TurkishStudies.53947

Received/Geliş: 23 October/Ekim 2021

Accepted/Kabul: 27 December/Aralık 2021

Published/Yayın: 31 December/Aralık 2021

Checked by plagiarism software

CC BY-NC 4.0
} 
control was ensured and past retouching/overpaintings was tried to be determined with UV-light. Within the framework of analytical studies and observations, conservation suggestions were presented such as drainage and temporarily roof covering on wall paintings, cleaning process of the fresco painting technique, removing the white layer based on limestone and preventing the plant growth.

Structured Abstract: The ancient city of Hadrianoupolis is located in $3 \mathrm{~km}$ west of Eskipazar district center in Karabuk province. There is not much data about the city, which was quite substantial city in the late Roman and Byzantine periods after the 8th century AD. Excavations and surface surveys of the city have been carried out since 2003. There are wall paintings that constitutes the scope of our study in the building called the Late Roman Villa, located in 300 meters east of Church B (Church of the Four Rivers) of the city. 7 rooms of the house were excavated since 2007. Decorative wall paintings in room 3, room 4 (triclinium) and room 5 constitute the subject of this study. The scientific and technical preliminary examinations were carried out only on the wall paintings of room 3 between 2-6 August 2021. During the short period, it would be very difficult to monitor the ambient conditions with a certain number of restorer team.

It has been observed that regular monitoring have been carried out on the wall paintings since 2010 . After each monitoring, geotextile, windshield, fine sand and bricks were used as preventive conservation. In the past restorations, Malta 6001 was applied for the plaster consolidation process, Primal-AC33/ParaloidB72 for fixing the pigments on the painting surface, and EDTA (Ethylenediaminetetraacetic acid) for the salt removing process. In addition, the missing parts of the plasters and plaster borders were completed regularly in every past restorations. In the observations, white stratification on the painting surfaces, damp wall due to high humidity and some plant growths were observed on the wall and wall paintings. Previous conservation interventions such as filling the borders and missing parts (lacuna) were also observed. The protection cover on wall paintings respectively consists of one layer of geotextile cover, one layer of windshield, fine sand and 1-3 layers of bricks. After the preliminary examinations, it was covered in the same way using a new geotextile and windshield. In the removal process of the room facing east, a temporary awning was prepared to block the sun before removing the geotextile cover. In order to remove the geotextile, the sun was expected to move to the west side in the evening hours. Thus, it is ensured that the paintings are minimally damaged by the heat of the sun. In addition, the old geotextile cover was wrapped outside the sun awning, and the effect of the sun's rays was tried to be minimized by providing reflection. During 5 (five) days, it is carried out humidity control, sampling for analytical research, monitoring the borders and lacunas, monitoring the gaps and the back of paint surface, observations with UV-light and documentation studies.

For scientific and technical studies; thin-section petrography with LEICA Research Polarizan DMLP, optical microscope (OM) images with Olympus GX41, IR spectra with Bruker ALPHA-ATR, X-Ray Fluorescence Spectrometer (XRF) measurements with Spectro Xepos II, X-Ray Diffractometer (XRD) measurements with Inel Equinox 1000, Confocal Raman Spectrometer (CRS) measurements with Thermo Scientific DXR were made.

In the optical microscope images, it is seen that the final plaster layer and the painting layer are the same. No other binding materials except restoration materials could be detected in the IR spectra. It supports that the paintings may have been made on wet plaster (fresco). In the observations, no other traces of the drawing techniques (engraving, coal dust, sinopia drawing, pencil marks, etc.) were found on the paintings of Room-3. However, some color stains were observed which may had been dropped by artists. No traces of reintegration or overpainting were found on the paintings in the UV-light examinations. One of the two important problems ise white layer on the painting surface, and the other one is plant growth. Plant growth has not yet been caused cracking, scattering, etc. on the painting surface and plaster layers. In XRD measurements, no crystal structure was found except the formation of calcite. Therefore, it is supposed to be $\mathrm{CaCO}_{3}$ formation on the white surface. In CRS measurements, black colors may be based on carbon; red, green and yellow colors based on siderite $\left(\mathrm{FeCO}_{3}\right)$. In XRF, it is measured that mortars and renders are medium hydraulic and natural cement properties according to cementation index.

It was understood that the geotextile cover can keep in constant moisture, but not prevent the formation of high humidity. In order to solve this problem, additionally, the rooms should be covered with a wooden roof after providing drainage around the rooms. Accordingly, conservation treatment should be started after the moisture problem is solved. The mechanical cleaning method on white layer of the paintings is a respective method without using chemicals, but it is a long-term process. Since "water and ethanol" are not a risk factor for frescoes, they can be used for mechanical cleaning and surface softening. If chelating 
agents are prefered, it is needed to be careful for removing it from the painting surface. Herbicide materials should be used for plant growth. After the surface cleaning of the paintings, UV-light examinations should be re-examined in order to observe the traces of drawing techniques such as giornata, engravings, pencil marks and charcoal dust. As a result, the preliminary studies indicate important clues in terms of the conservation plan and the use of materials on the wall paintings of the Late Roman Villa. It could be supported by more detailed scientific studies in the future.

Keywords: Wall Painting Conservation, Hadrianoupolis, Roman Villa, FTIR, XRF, XRD, Raman Spectroscopy.

Öz: Karabük Hadrianoupolis Antik Kenti, Geç Roma Villası'nda bulunan duvar resimleri üzerinde gerçekleştirilen ön inceleme çalışmalarından oluşmaktadır. İnceleme çalışmalarında resimlerin korunma durumları, restorasyon geçmişi, nem koşulları, UV- ampul görünümleri, optik mikroskop görüntüleri ile boya ve sıvalardan alınan numunelerin analitik ölçümleri değerlendirilerek korunma süreçlerinde uygulanabilecek öneriler getirilmiștir. Villa'da Oda-3, Oda-4 ve Oda-5'de yer alan resimlerden yalnızca Oda-3'ün koruma örtüsü kaldırılarak numuneler alınmış; FTIR (Fourier Dönüşümlü Kızılötesi) Spektroskopisi, XRF (X-Işını Floresans), XRD (X-1şını difraksiyonu), KRS (Konfikal Raman Spektroskopisi), ince-kesit petrografi ve sıvaboya katmanlarının belirlenebilmesi için en-kesit optik mikroskop görüntüleri incelenmiştir. IR spektrumlarında kireç, sülfat tuzları ve restorasyonda kullanılan akrilik reçinelere; XRF ölçümlerinde orta hidrolik ve doğal çimento özellikli harçlar; XRD ölçümlerinde kalsit kristal yapısına; KRS ölçümlerinde karbon ve siderit $\left(\mathrm{FeCO}_{3}\right)$ kaynaklı pigmentlere; ince-kesit petrografide tuğla kırıklı ve kıtıklı harçlara; enkesit optik mikroskop incelemelerinde fresko tekniği görüntülerine rastlanmıştır. Duvar resimlerinin koruyucu örtüsünün kaldırılması ile başlayan ve yeni bir örtü ile kapatılması ile tamamlanan 5 günlük ön inceleme çalışmasında \%80 bağıl nemdeki sıva ve duvarların nem değişimleri ölçülmüş, nem kontrolü sağlanmış, UV-ampul ile rötuş ve üzerine boyamaların tespiti yapılmaya çalışılmış, bordür ve lakunalar kontrol edilmiştir. Analitik incelemeler ve gözlemler çerçevesinde resimlerin bulunduğu kısımların diş etkenlere karşı geçici olarak çatı ile kapatılması, fresko resim tekniğine uygun temizlik müdahalesi, yüzeydeki kalker kaynaklı beyaz tabakanın kaldırılması ve bitki gelişimi ile mücadele konularında koruma önerileri sunulmuştur.

Anahtar Kelimeler: Duvar Resmi Koruma, Hadrianoupolis, Roma Dönemi Villası, FTIR, XRF, XRD, Raman Spektroskopisi

\section{Giriş}

Hadrianoupolis antik kenti Karabük ili, Eskipazar ilçe merkezinin $3 \mathrm{~km}$ batısında bulunmaktadır. Kalıntılar Budaklar Köyü ve Hacı Ahmetler Mahallesi'nde yoğunlaşmaktadır (Keleş vd., 2011, s. 39; Kılavuz \& Çelikbaş, 2013, s. 160-161). Antik kent, Paphlagonia, Bithynia ve Galatia bölgeleri sınırında yer alan bir Güney Paphlagonia olarak Roma'nın bölgede kurduğu en önemli yerleşimlerden biridir (Şekil 1). Bu doğrultuda 2003 yılından beri yüzey araştırmaları ve kazı çalışmaları sürdürülmektedir (Laflı, 2008, s. 399; Kılavuz ve Çelikbaş, 2013, s. 160-161). 2011 yılında antik kentin çevresinde yapılan yüzey araştırmaları sonucunda kentin Roma döneminde bölge ticareti için önemli bir pazar yeri olduğu anlaşılmaktadır (Kılavuz \& Çelikbaş, 2013, s. 161). Geç Roma ve Bizans dönemlerinde oldukça parlak olan kentin MS 8. yüzyıldan sonrasında kullanımına ait fazla veri yoktur (Keleş, Çelikbaş \& Yılmaz, 2011, s. 39; Keleş \& Çelikbaş, 2013, s. 367; Kılavuz \& Çelikbaş, 2013, s. 161-162). 2003 yılından beri yapılan ve günümüzde de devam eden kazılar sonucunda Hamam A, Hamam B, Kilise A, Kilise B ve Geç Roma Villası yapılarının kazıları tamamlanmıştır (Laflı, 2009, s. 43; Keleş vd., 2011, s. 46; Kılavuz \& Çelikbaş, 2013, s. 162; Çelikbaş \& Ekinci, 2021, s.155-160). 


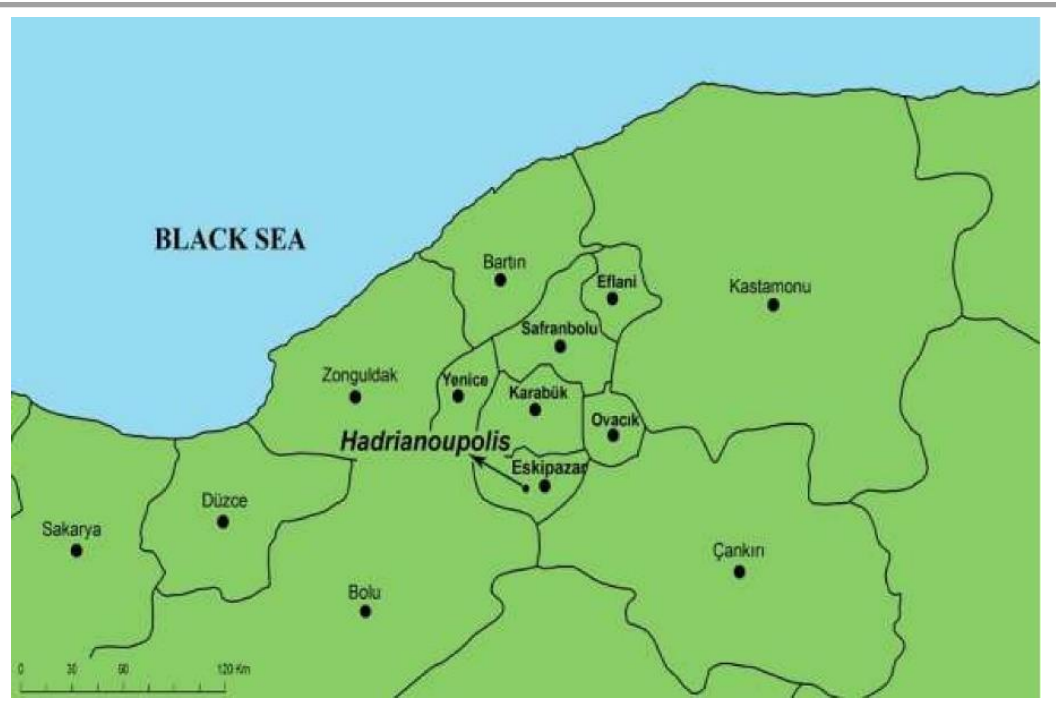

Şekil 1: Hadrianoupolis Antik Kenti’nin haritadaki konumu (Kılavuz \& Çelikbaş, 2013, s. 183).

Kentin Kilise B (Dört Nehirler Kilisesi)'nin 300 m doğusunda yer alan ve Geç Roma Villası olarak adlandırılan yapının içinde çalışmamızın kapsamını oluşturan duvar resimleri bulunmaktadır. 2007 yılından itibaren kazılan konutun 7 mekânı ortaya çıkarılmıştır. Konutta bir atrium (Oda- 1) bulunmakta ve tüm odalar atriuma açılmaktadır (Laflı, 2009, s. 51; Kılavuz \& Çelikbaş, 2013, s. 172-173; Çelikbaş \& Ekinci, 2021, s.155-160). Atriuma aç1lan odalardan biri yemek odas1 olarak kullanıldığı düşünülen tricliniumdur. Konutun kuzeybatı köşesinde konumlanan cubiculum (Oda- 6) ve güney cephedeki Oda- 7'nin yapıya sonradan eklendiği düşünülmektedir (Şekil 2). Geç Roma - Erken Bizans özelliklerini gösteren yapının ilk evresinin MS 5. yüzyıl, ikinci evresinin ise MS 6-7. yüzyıl olduğu düşünülmektedir (Kılavuz \& Çelikbaş, 2013, s. 173; Çelikbaş \& Ekinci, 2021, s.155-160).

Oda- 3, Oda- 4 (triclinium) ve Oda- 5 içinde yer alan dekoratif duvar resimleri çalışmanın konusunu oluşturmakta; ancak önleyici koruma çerçevesinde koruma örtüsü (jeotekstil) ile kapatılmıştır. Koruma örtüsünün kaldırılması resimlerin sabit ortam koşullarını değiştirecektir. Dolayısıyla, kısa zaman aralığında tüm resimlere yapılacak bir örtü kaldırma işleminde ortam koşullarının kontrolü ve takibi oldukça zor olacaktır. Yaz sıcağının resimlere etkisi de düşünülürse nem koşullarının hızlı değişimi sorunun çözümünü zorlaştıracaktır. Bu sebeple resimlerin koruma süreci kapsamında bilimsel ve teknik anlamda yapılan ön incelemeler yalnızca Oda- 3'ün duvarlarında yer alan resimler üzerinde 2-6 Ağustos 2021 tarihleri aralığında yapılmıştır.

Araştırma Hadrianoupolis antik kentinde Geç Roma Villası'nda yer alan duvar resimlerinin korunma sürecindeki restorasyon müdahaleleri için gerekli bilimsel çalışmaları içermektedir.

\section{Duvar Resimlerinin Korunma Durumu}

Geç Roma Villası olarak adlandırılan konutun atriuma açılan ve batı cephesindeki ana kayaya yaslanmış duvarın sırasındaki Oda- 3, Oda- 4 (triclinium) ve Oda- 5'te dekoratif duvar resimleri bulunmaktadır. Atrium ve tricliniuma (doğu ve kuzey yönlerinde) kapı açıklığı bulunan Oda- 3'ün, yoğun olarak batı cephesinde bulunan resimleri, oda duvarlarının alt kısımlarda kuzey ve güney cephelerine doğru yayılmaktadır. Atriuma girişi bulunan Oda- 5'in batı ve kuzey cephelerinde, tricliniumun (Oda- 4) ise kuzey ve batı duvarının birleştiği köşelerde resimler yer almaktadır (Şekil 2).

\section{Önceki koruma-onarım müdahaleleri:}

Geç Roma Villası'nda 2007 yılında başlayan (Laflı, 2009, s. 51) kazılar henüz tamamlanmamış olup, 2010 yılından itibaren (Kılavuz \& Çelikbaş, 2013, s. 172) yalnızca koruma- 
onarım çalışmaları ile devam etmiştir. 2010 yılından itibaren duvar resimlerinin düzenli olarak bakım çalışmalarının yapıldığı görülmektedir. Her bakım müdahale sonrasında sırası ile jeotekstil, sinek teli, ince kum ve bir sıra tuğla ile önleyici koruma olarak kapatma yapıldığg görülmektedir. Sıva sağlamlaştırma işlemlerinde Malta 6001, resim yüzeyindeki pigment/boyaların sabitlenmesinde Primal-AC33/Paraloid-B72, tuz alımı işlemlerinde ise EDTA (Ethylenediaminetetraacetic acid)'y1 kağıt hamuru ile paketleme yöntemlerinin kullanıldı̆̆ bilinmektedir. Ayrıca yine düzenli olarak sıvalardaki kayıp kısım tamamlamaları ve sıva bordür işlemleri yapılmışıır' ${ }^{1}$.

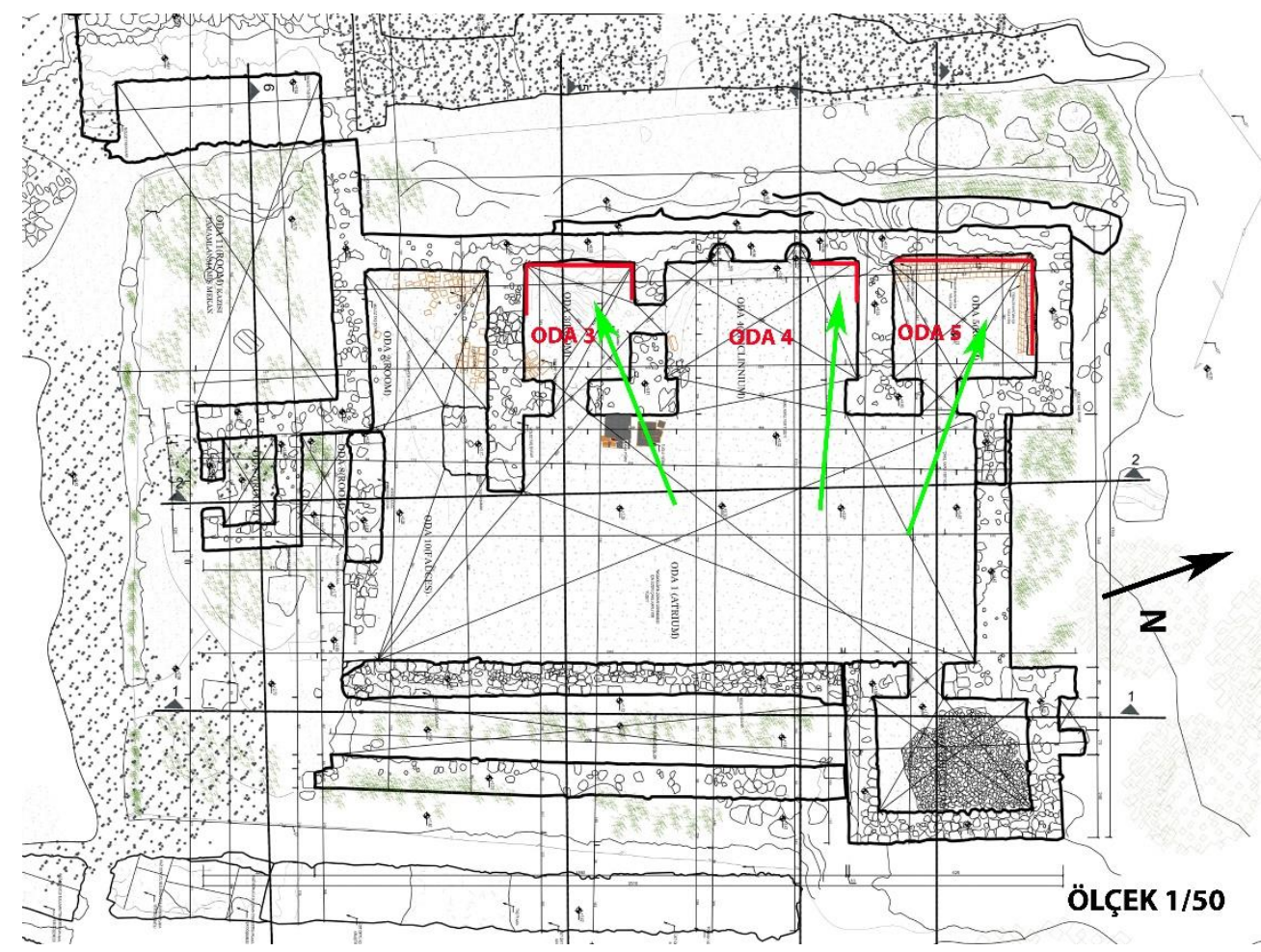

Şekil 2: Hadrianoupolis Antik Kenti, Geç Roma Villası çizimi ve duvar resimlerinin konumları (Hadrianoupolis Antik Kenti kazı arşivi belgeleri).

\section{Mevcut durum ve müdahaleler:}

Roma villasında bulunan duvar resimlerinin 2021 Ağustos ayında koruma çalışmaları kapsamında ön incelemeleri yapılmıştır. Yukarıda da belirtildiği gibi, zaman, bütçe ve ortam koşullarının dezavantajı dolayısı ile ön inceleme çalışmaları Oda- 3 'te yer alan resimler üzerinde yapılmıştır. $\mathrm{Bu}$ çalışmalar ileriki günlerde duvar resimleri üzerinde yapılacak olan koruma çalışmalarının planlanması için teknik bir alt yapı oluşturacaktır.

\footnotetext{
${ }^{1}$ Hadrianoupolis Antik Kenti kazı arşivi belgeleri.
} 

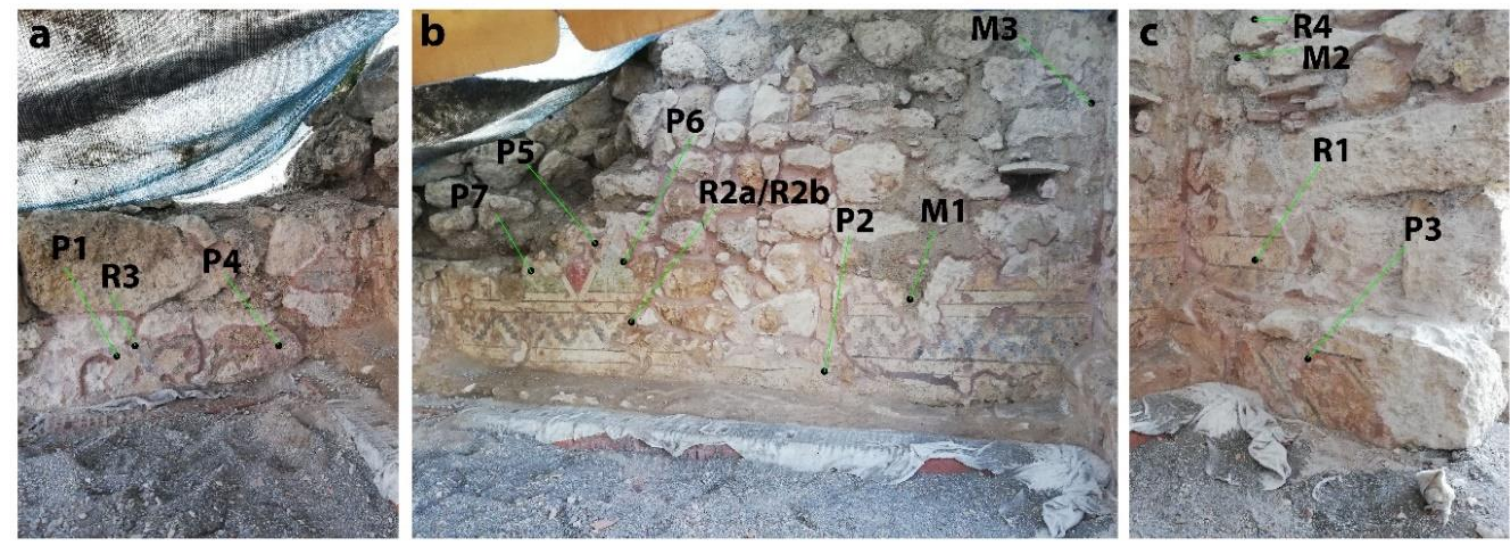

Resim 1: Karabük Hadrianoupolis Antik Kenti, Geç Roma Villası, Oda-3, a. güney duvarı, b. Batı duvarı, c. kuzey duvarı. Alınan sıva ve boya numunelerinin konumları (E. Yetiş).

Oda- 3'teki dekoratif resim odanın batı duvarında yoğunlaşmakta, kuzey ve güney duvarlarının az bir kısmında devam etmektedir (Şekil 2 ve Resim 1). Odanın taban döşemesi üzerinde yaklaşık $80 \mathrm{~cm}$. yüksekliğe erişen jeotekstil, kum ve çakıl örtüsü bulunmaktadır. Ön inceleme için resimler taban döşemesine kadar açılmamıştır. Bununla birlikte Oda-3'teki incelemelerin koruma müdahaleleri ile ilgili yapılacak bilimsel ve teknik araştırmalar için yeterli olduğu düşünülmektedir. Çıplak göz ile yapılan gözlemlerde duvar resimlerinde bazı noktalarda farklı dönem olduğu düşünülen sıva katmanları, resim yüzeyinde beyaz tabaka, yüksek nemden kaynaklı 1slaklık ile duvar içinde bazı bitki gelişimleri tespit edilmiştir. Ayrıca bordür ve kayıp kısımların (lakuna) dolgulanması gibi önceki koruma müdahaleleri de gözlemlenmiştir (Resim 2).
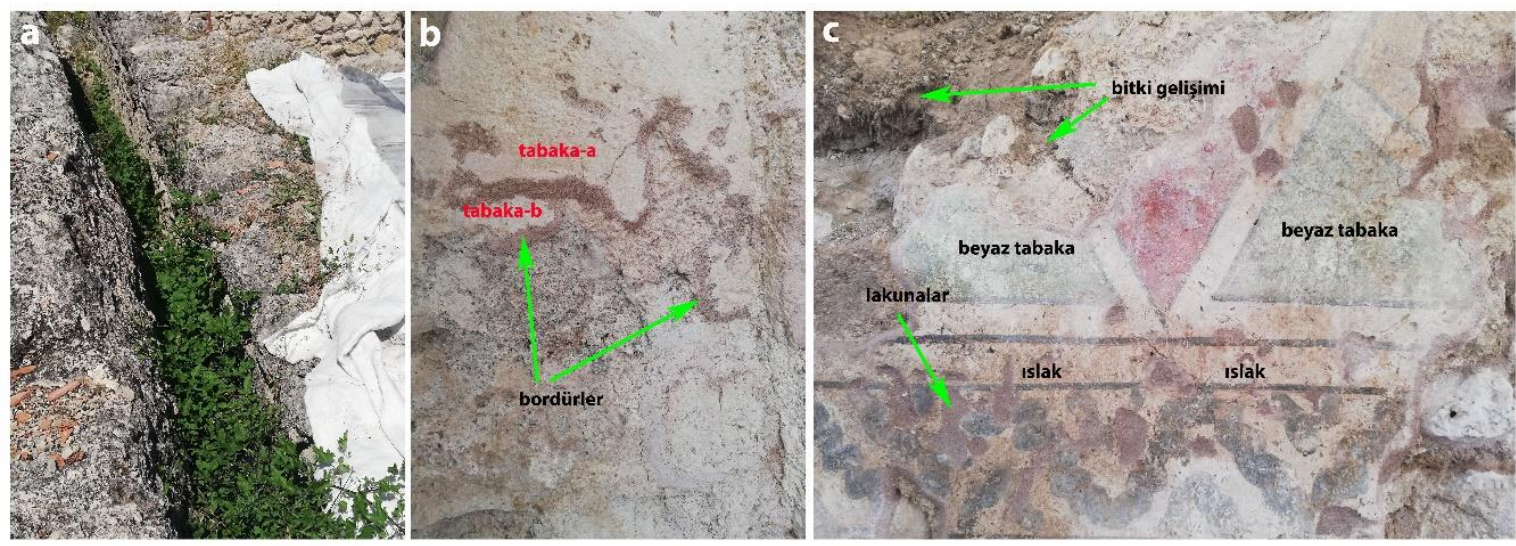

Resim 2: Geç Roma Villası, Oda- 3. a- duvar üzerindeki bitki gelişimi, b- sıva tabakaları ve bordürler, c- beyaz tabaka, 1slak bölgeler, lakunalar ve bitki kökleri (E. Yetiş).

Ön incelemesi yapılan resmin içinde bulunduğu Oda- 3'ün duvar üstlerinde ve duvar örgüsü içinde bitki köklerinin yayıldığ 1 görülmektedir (Resim 2a ve 2c). Mevcut durumda resim yüzeyi ve sıvasında bir tehlike oluşmasa da, ileriki günlerde daha da yayılması resimlere zarar verecektir.

Resimlerin sıva sağlamlaştırmaları için yapılan sıva bordürleri ve kayıp kısım dolgularının (lakuna) kahve-kırmızı renklerde olduğu görülmektedir. Bu durum bordür ve lakuna dolgularını kromatik olarak ön plana çıkarmakta ve resmin görsel olarak algılanmasını zorlaştırmaktadır².

\footnotetext{
${ }^{2}$ Tarihi resimlerin algılama güçlüklerinin sebepleri ile ilgili daha detaylı bilgi için bakınız Yetiş (2021, s.17-36).
} 
Bununla birlikte genel olarak bakıldığında 2007 yılından itibaren yapılan bakım çalışmaları sonucunda resimlerin yüzey ve sıva arkalarının oldukça iyi durumda olduğu; boya tabakasında dökülme, tozlanma ya da yapraklanma gibi risklerin olmadığı anlaşılmaktadır. Ancak resim yüzeyinin neredeyse tümüne beyaz bir tabaka ve buna bağlı olarak resmin güçlükle algılanmasına sebep olan puslu bir görünüm hâkimdir.

4-8 Ağustos 2021 tarihleri arasında Oda- 3'ün koruma örtüsü kaldırılarak ön inceleme çalışmaları gerçekleştirilmiştir. Koruma örtüsü duvar resimlerinin bulunduğu kısımlarda sırasıyla; bir sıra jeotekstil örtü, bir sıra sinek teli, dere kumu ve 1-3 sıra tuğladan oluşmaktadır. Sinek teli kumun jeotekstil ile temasını engellemektedir. Tuğla örgü ile sinek teli arasında kalan yaklaşık 5$10 \mathrm{~cm}$. boşluğu dere kumu doldurmaktadır (Neguer \& Alef, 2014, s. 23; Eryurt \& Özdemir, 2020, s. 106). Ayrıca delikli tuğlalar delikleri üste gelecek şekilde yerleştirilmiş ve deliklerine kum doldurularak ağır ve sabit kalması sağlanmıştır. Tuğla sırası alt kısımlarda 3 sıra, yukarı doğru 2 ve tek sıra olarak dengeli ve güvenli şekilde yerleştirilmiştir. Ön inceleme sonrası yine aynı şekilde yeni bir jeotekstil ve sinek teli kullanılarak kapatılmıştır. Doğu yönüne bakan odanın örtü kaldırma işleminde tuğla, kum ve sinek teli kaldırıldıktan sonra jeotekstil örtü henüz kaldırılmadan odanın tamamına güneşi engelleyen geçici bir tente hazırlanmış; örtünün kaldırılması için güneşin akşam saatlerinde batı yönüne geçmesi beklenmiştir. Böylece resimlerin güneşin sıcağından ve ışınlarının etkisinden en az düzeyde zarar görmesi sağlanmıştır. Ayrıca eski jeotekstil örtü güneş tentesinin dış tarafına sarılarak, güneş ışınlarının yansıması sağlanmış, güneş etkisi aza indirilmeye çalışılmıştır. 1. ve 5. günler açma ve kapatma işlemlerinin gerçekleştirildiği toplam 5 günlük süreçte; nem kontrolü, analitik araştırmalar için numune alımı, bordür ve boşlukların (lakuna) kontrolü, sıva arkalarının boşluk ve boya yüzeyinin sağlamlık kontrolleri, UV-ampül ile gözlemler ve belgeleme çalışmaları yapılmıştır. Duvar resimlerine herhangi bir koruma müdahalesi yapılmaksızın, yeni jeotekstil örtü resimlerin üzerine örtüldükten sonra güneş tentesi kaldırılmış ve aynı kapatma işlemi gerçekleştirilmiştir.

\section{Bilimsel ve Teknik İncelemeler}

Örnekleme ve Analizler: Alınan numunelerin arşiv kodlamasında KHPrv kısaltması kullanılmış, ancak bu makalede kodlamada sadeleştirme yapılarak, R (render)- sıva tabakaları, P (paint layer)- resim tabakası ve $\mathrm{M}$ (mortar)- harç/moloz dolgu kısaltmaları tercih edilmiştir. Özellikle, numunelerde R2a ince sıvayı, R2b ise kaba sıvayı temsil etmektedir. R2a yüzeyden 5-10 $\mathrm{mm}$. derinlikte siva, R2b ise diğerinden daha derindeki sıvadır. İnce-kesit petrografi LEICA Research Polarizan DMLP model mikroskop, Optik mikroskop (OM) görüntüleri Olympus marka GX41 model mikroskop, IR spektrumları Bruker marka ALPHA model ATR başlıklı, X-Işınları Floresans Spektrometresi (XRF) ölçümleri Spectro marka Xepos II model, X-Işınları Difraktometre (XRD) ölçümleri Inel marka Equinox 1000 model, Konfokal Raman Spektrometre (KRS) ölçümleri Thermo Scientific marka DXR model cihazlarında yapılmıştır (Tablo 1) ${ }^{3}$.

\footnotetext{
${ }^{3}$ XRD ve KRS analizleri ile polarize mikroskop için Ankara Üniversitesi Yerbilimleri Uygulama ve Araştırma Merkezi (YEBİM) laboratuvarları kullanılmıştır. Diğer analiz ve ölçümler Kastamonu Üniversitesi Merkezi Araştırma Laboratuvarı Uygulama ve Araştırma Merkezi (MERLAB)'da yapılmıştır.
} 
Tablo 1: Hadrianoupolis Antik Kenti Roma Villası, Oda-3'ten alınan harç-sıva-resim tabakası numune örnekleri ve yapılan analizler (E. Yetiş, M. Eroğlu, K. Deniz, Y. K. Kadıoğlu).

\begin{tabular}{|c|c|c|c|c|c|c|c|}
\hline & Renk & OM & FTIR & XRF & PETRG. & XRD & KRS \\
\hline KHPrv-P1 & sar1 & - & $\begin{array}{l}\text { pr./par./kals./s } \\
\text { ülf./-OH }\end{array}$ & - & - & - & $\begin{array}{c}\text { sid. } \\
\left(\mathrm{FeCO}_{3}\right)\end{array}$ \\
\hline KHPrv-P2 & siyah & - & - & - & - & - & $\begin{array}{l}\text { karbon } \\
\text { (C) }\end{array}$ \\
\hline KHPrv-P3 & kırmızı & - & pr./par./kals. & - & - & - & $\begin{array}{c}\text { sid. } \\
\left(\mathrm{FeCO}_{3}\right)\end{array}$ \\
\hline KHPrv-P4 & k. yeşil & - & $\begin{array}{l}\text { pr./par./kals./s } \\
\text { ülf./-OH }\end{array}$ & - & - & - & $\begin{array}{c}\text { sid. } \\
\left(\mathrm{FeCO}_{3}\right)\end{array}$ \\
\hline KHPrv-P5 & kırmızı & fresko & pr./par./kals. & - & - & - & - \\
\hline KHPrv-P6 & a. yeşil & fresko & pr./par./kals. & - & - & - & $\begin{array}{c}\text { sid. } \\
\left(\mathrm{FeCO}_{3}\right)\end{array}$ \\
\hline KHPrv-R1 & - & - & - & - & $\begin{array}{l}\text { Q, Pl, Op, Ç, K, } \\
\text { Tk, Kıtık }\end{array}$ & kalsit & - \\
\hline KHPrv-R2a & - & $\begin{array}{l}\mathrm{kal} / \mathrm{kir} \\
\text { tab. }\end{array}$ & - & OHK & $\begin{array}{c}\text { Q, Pl, Op, Ç, K, } \\
\text { Tk, Kitık }\end{array}$ & - & - \\
\hline KHPrv-R2b & - & - & - & HK & - & - & - \\
\hline KHPrv-R3 & - & - & - & - & $\begin{array}{l}\text { Q, Pl, Op, Ç, K, } \\
\text { Tk, Kitık }\end{array}$ & kalsit & - \\
\hline KHPrv-R4 & - & - & - & OHK & $\begin{array}{c}\text { Q, Pl, Op, B, Tf, } \\
\text { K, Tk, Kitık }\end{array}$ & - & - \\
\hline KHPrv-M1 & - & - & - & $\mathrm{DÇ/Ç}$ & - & - & - \\
\hline KHPrv-M2 & - & - & - & $\mathrm{DC} / \mathrm{C}$ & - & - & - \\
\hline KHPrv-M3 & - & - & - & $\mathrm{DÇ/Ç}$ & $\begin{array}{l}\text { Q, Pl, Op, B, M, } \\
\quad \text { R, Kst, Tk }\end{array}$ & - & - \\
\hline
\end{tabular}

* Q: Kuvars, Pl: Plijoklaz, K: Kireç taşı, Kmt: Kum taşı, Çmt: Çamurtaşı, Op: Opak mineraller, Tk: Tuğla kırı̆̆ı, Ç: Çört, B: Bazalt, Tf: Tüf, R:Radiolarit, M: Mermer, Kst: Kuvarsit, Pr: Primal AC33, Par: Paraloid B72, Sülf: sülfat, Kals: kalsit, Sid: siderit, Kal: Kalker, DÇ: doğal çimento, HK: hidrolik kireç, OHK: ortalama hidrolik kireç

En-kesit incelemeleri $(O M)$ : P5, P6 ve R2a numuneleri şeffaf reçine içerisine gömülmüş ve enine kesilerek zımpara makinesinde parlatılmıştır. Alttan aydınlatmalı optik mikroskopta (OM) reçine içindeki numuneler incelenmiş ve resimlerin yapım tekniklerine dair gözlemler yapılmaya çalışılmıştır (Resim 3). Görüntülerde kalınca bir resim tabakasına rastlanmamış ve resim yüzeyini oluşturan oldukça ince bir pigment tabakasının oluşumu tespit edilmiştir. Bu durum resimlerin yaş sıva üzerine (fresko) yapıldığına işaret edebilir. Aksine kuru sıva üzerine bağlayıcı madde (yumurta, kazein hayvan tutkalı gibi) ${ }^{4}$ kullanılarak yapılan teknik ile kireç-boya tekniklerinde resim tabakası daha kalın ve farklı görüntüler verecektir (Ajò vd., 2004; Piovesan vd., 2012). Bununla birlikte Resim 3a ve 3b'deki görüntülerde resim yüzeyi üzerinde beyaz tabaka ile kir tabakasının oluştuğu görülmektedir. Hatta bu tabakalar Resim 3b'de oldukça kalındır.

\footnotetext{
${ }^{4}$ Duvar resimlerinde kullanılan bağlayıcı maddeler ile ilgili bakınız Zadrozna vd. (2003, s.996-1004), Casadio vd. (2004, s.63-80), Yetiş (2019, s.507-530).
} 

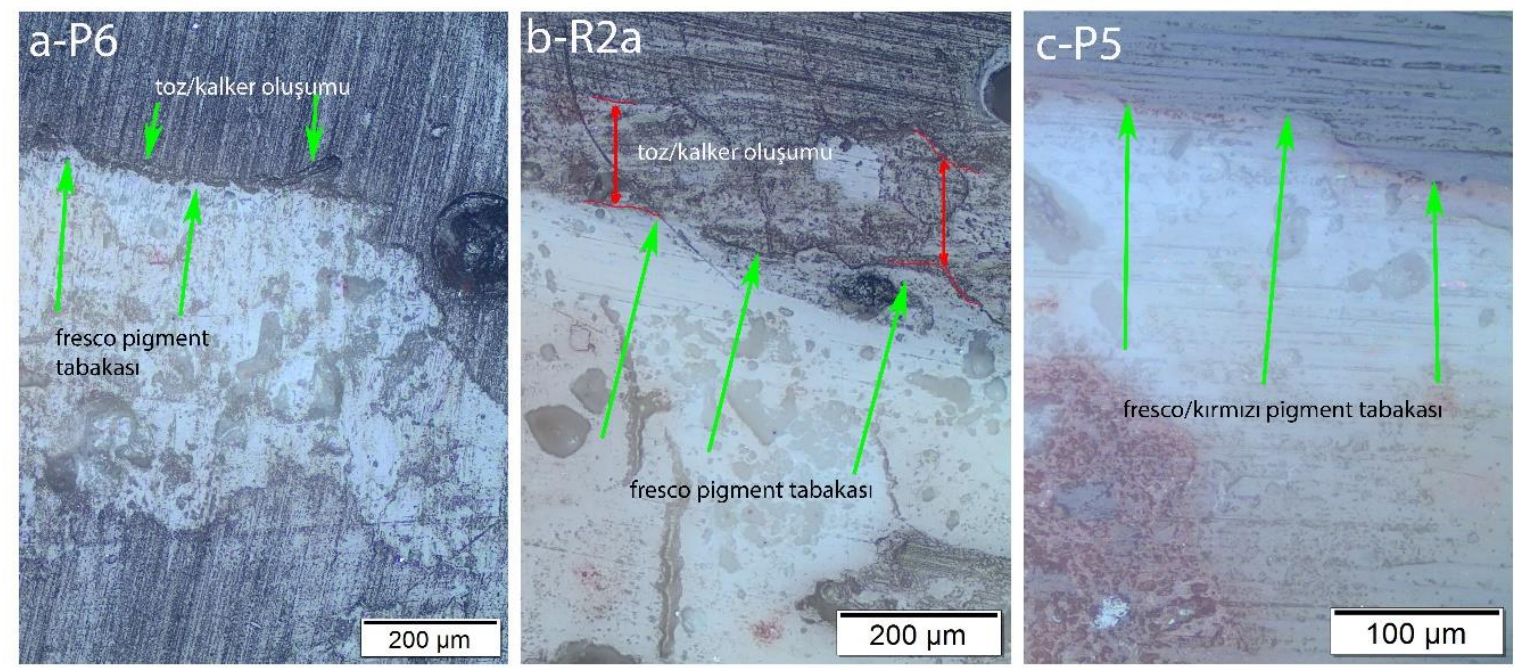

Resim 3: En-kesitlerin optik mikroskop görüntüleri. a- KHPrv-P6, b- KHPrv-R2a ve KHPrv-P5 numuneleri (E. Yetiş).

FTIR: P1, P3, P4, P5 ve P6 numunelerinin IR spektrumları ölçülmüştür. Genellikle resim tabakasından alınmaya çalışılan numunelerin özellikle pigment yüzeylerinden kazıma yapılarak toz halinde cihaz ölçümleri yapılmıştır. P1'de 3531, 3486 ve $3398 \mathrm{~cm}^{-1}$ 'de görülen pikler -OH grubunun gerilme titreşimleri ve su molekülünün eğilme titreşimlerine bağlı olarak kristalize suyun varlığına işaret etmektedir (Ajò vd., 2004, s.339-340; Sarmiento vd., 2011, s. 3605). Diğer numunelerde belirgin bir hidrat suyu varlığına rastlanmamıştır (Şekil 3). 


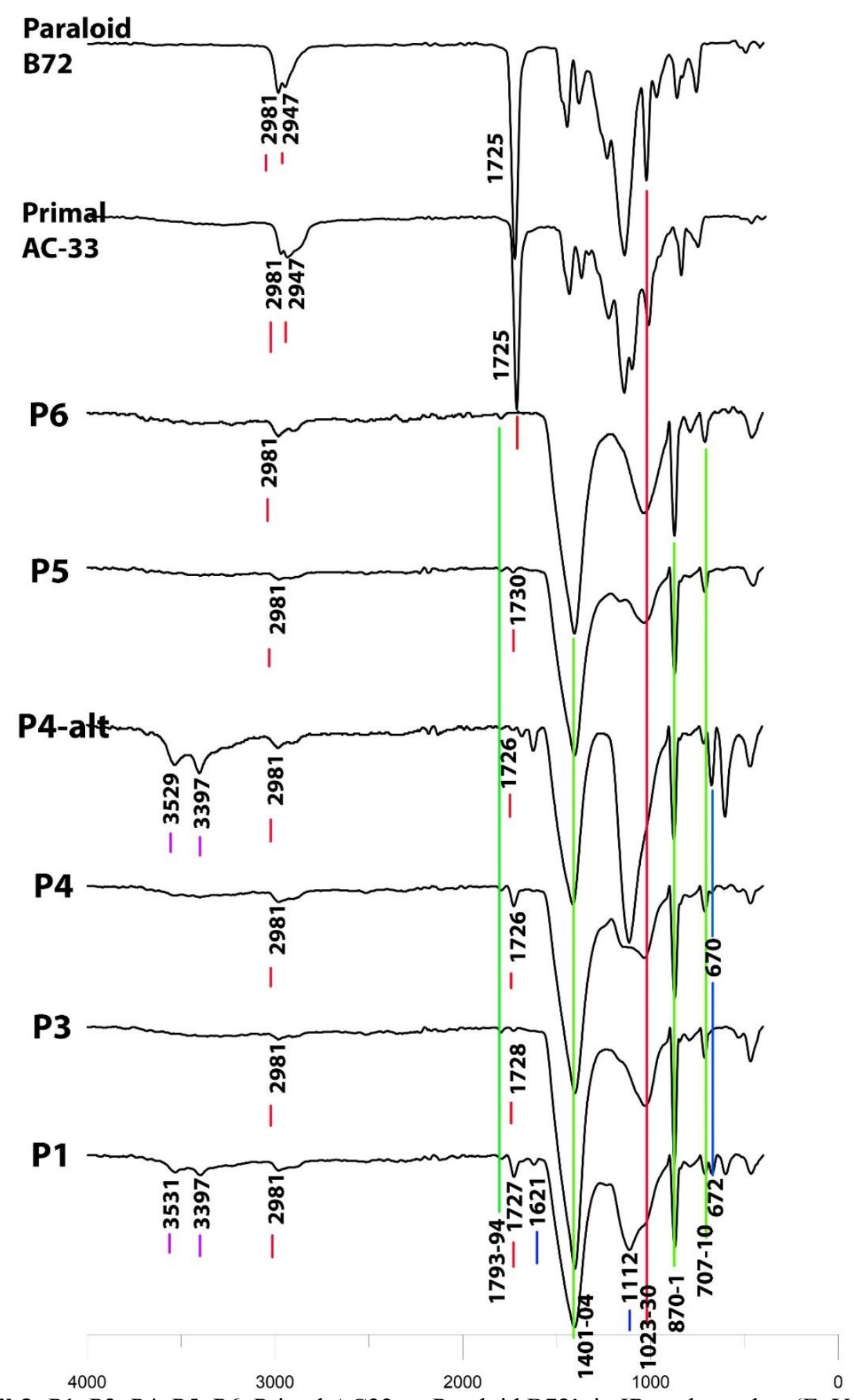

Şekil 3: P1, P3, P4, P5, P6, Primal AC33 ve Paraloid B72'nin IR spektrumları (E. Yetiş). 
Yine P1'de 1621, 1112 ve $672 \mathrm{~cm}^{-1 ،}$ deki S-O gerilme titreşimleri sülfat tuzlarını göstermektedir (Poliszuk \& Ybarra, 2013, s.6). S-O gerilme titreşimlerine P4 numunesinde $677 \mathrm{~cm}^{-}$ ${ }^{1}$ 'de rastlanmaktadır (Şekil 3).

Tüm numunelerde 1401-1404 $\mathrm{cm}^{-1}, 870-871 \mathrm{~cm}^{-1}, 707-710 \mathrm{~cm}^{-1}$ aralıklarında kalsitten kaynaklı (Ajò vd., 2004, s. 343-345; Vahur vd., 2016) gerilme ve düzlem dışı eğilme pikleri gözlemlenmiştir. Ayrıca tüm numunelerde $1793-1794 \mathrm{~cm}^{-1}$, de karbonil gerilme titreşimlerine de rastlanmaktadır (Şekil 3).

P6 haricinde tüm numunelerde oldukça şiddetli $\mathrm{C}=\mathrm{O}$ gerilme bantları $1726-1730 \mathrm{~cm}^{-1}$ aralığında; tüm numunelerdeki C-H gerilme bantları 2980 ve $2947 \mathrm{~cm}^{-1}$ aralığında görülmektedir. Organik bileşikleri (alifatik) ifade eden bu pikler (Derrick vd., 1999, s. 95), Primal AC33 ve/veya Paraloid B-72 reçinelerini işaret edebilir. Ayrıca P1 haricinde tüm numunelerde 1029-1032 $\mathrm{cm}^{-1}$ aralığında görülen pikler yine Primal AC33 ve/veya Paraloid B-72'ye ait olabileceği düşünülen C$\mathrm{O}$ gerilme bantları olabilir. Zaten önceki restorasyon müdahalelerinde her iki reçinenin de kullanıldığ 1 belirtilmiştir. OM görüntülerinde bağlayıcı maddenin kullanıldığı herhangi bir sekko boya tabakasına rastlanmamıştır. $\mathrm{Bu}$ durum duvar resimlerinde kullanılan organik maddelerin (yumurta, hayvan tutkalı, kazein vb.) ${ }^{5}$ şüphesini azaltmakta, bizi restorasyonda kullanılan akrilik reçinelere (Primal AC33 ve Paraiod B-72) yönlendirmektedir. Daha önce kullanıldığ EDTA (Ethylenediaminetetraacetic acid)'ya ait herhangi bir tespit yapılamamıştır. Bu durum yüzeydeki kalıntının azlığı ve ölçümün hassaslığı ile ilgili olabilmektedir (Şekil 3).

Bununla birlikte P4 numunesinin resim tabakası arkasından alınan örnek ile yapılan FTIR ölçümlerinde akrilik reçine ve kalsit pikleri ile birlikte hidrat suyu $(-\mathrm{OH})$ ve $1618,1108,669 \mathrm{~cm}^{-1}$ bantlarında sülfat tuzlarına işaret eden S-O gerilme titreşimlerine rastlanmıştır.

UV-ampül incelemeleri: İncelemelerde blacklight blue ${ }^{6}$ özellikli ultraviyole ampul kullanılmıştır. Işığın az olduğu gece karanlığında resim yüzeyindeki kontrast alanlar tespit edilmeye çalışılmıştır. Burada özellikle yaş sıva (fresko) ve kuru sıva (sekko) tekniklerinin birlikte kullanıldığı alanlarda ultraviyole ampulün verdiği 1şık farklı parlaklıkta yansıma yapacaktır. Ancak küçük boyutlarda toz ve tüy (jeotekstil kaynaklı) haricinde yüksek parlaklığa sahip alanlar tespit edilememiştir. FTIR spektrumlarında da görünen Primal AC33 ve Paraloid B-72 reçinelerinin UV incelemelerinde görünmesi beklenmekteydi, ancak resim yüzeyindeki beyaz tabakanın bunu engellediği düşünülmektedir (Resim 4).

\footnotetext{
${ }^{5}$ Duvar resimlerinde kullanılan bağlayıcı maddeler ile ilgili bakınız Zadrozna vd. (2003, s.996-1004), Casadio vd. (2004, s.63-80), Yetiş (2019, s.507-530).

${ }^{6}$ Blacklight blue: Genellikle 400-315 nm aralı̆̆ında dalga boyuna sahip mor ışık yayan ampüllerde camda kullanılan özel filtre ile görünür 1şık bölgesindeki $(400-460 \mathrm{~nm})$ 1şınların geçmesi engellenir. Böylece yalnızca uzun dalga mor 1şılkların sanat eserine yansıması sağlanır (Blackligth Blue, t.y.).
} 

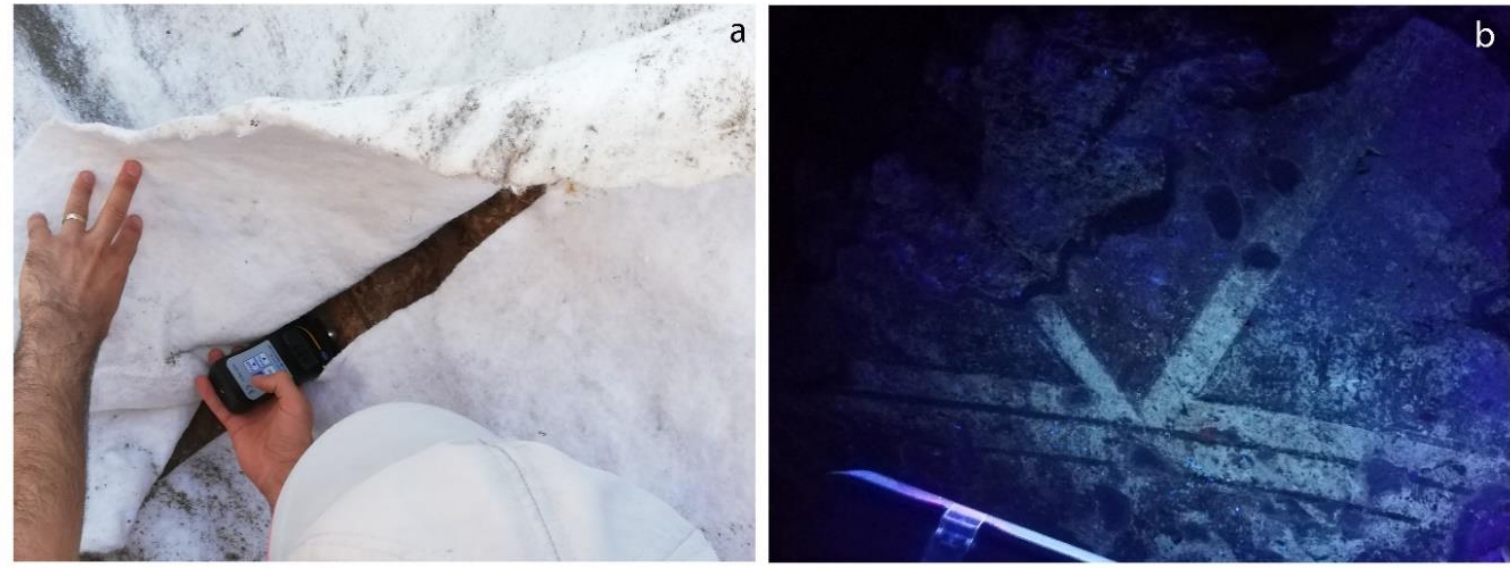

Resim 4: a- Jeotekstil örtü altından duvar resimlerinin nem ölçümlerinin yapılması, b- Duvar resimlerinin karanlık ortamda U-ampul ile incelenmesi (E. Yetiş).

Nem ölçümleri: Ölçümlerde PCR marka PCR-PMI2 model yüzey nemini ölçen taşınabilir bir cihaz kullanılmıştır. 4 Ağustos 2021 tarihinde jeotekstil önündeki tuğla sıraları, kum ve sinek teli kaldırıldığında, resimler henüz 1şık ile doğrudan veya dolaylı temas kurmadan önce ölçümler yapılmıştır. İlk ölçümlerde yüzeyin bağıl nemi yaklaşık olarak \%70-80 olarak ölçülmüştür.

Tablo 2: Hadrianoupolis Antik Kenti Roma Villas1, Oda-3'n duvar resimlerinin ön inceleme sürecindeki nem ölçümleri (E. Yetiş).

\begin{tabular}{lllll}
\hline & 1.Seviye* & 2.Seviye* & 3.Seviye* & 4.Seviye* \\
\hline 1.Gün & $\% 70-80$ & $\% 60-70$ & $\% 60-70$ & $\% 60-70$ \\
2.Gün & $\% 65-70$ & $\% 60-70$ & $\% 50-60$ & $\% 50-60$ \\
3.Gün & $\% 50-60$ & $\% 40-50$ & $\% 30-40$ & $\% 30-40$ \\
4.Gün & $\% 30-40$ & $\% 30-40$ & $\% 25-30$ & $\% 20-25$ \\
5.Gün & $\% 30-35$ & $\% 30-35$ & $\% 20-25$ & $\% 20-25$ \\
\hline
\end{tabular}

* 1.Seviye duvar resminin en altı (dip), 4.Seviye ise en üstüdür. Seviyeler arasında yaklaşık olarak 20-30 $\mathrm{cm}$ mesafe bulunmaktadır.

4-8 Ağustos 2021 tarihleri arasında yapılan ön inceleme çalışmalarında, belirtildiği gibi koruma örtüsü kontrollü bir şekilde açılarak doğrudan güneş 1şığı ile teması kesilmiştir. Bunun sebebi henüz jeotekstil örtü kaldırılmadan önce (1.gün) yapılan nem ölçümlerinin oldukça yüksek çıkması ve buna bağlı olarak nemin kontrollü bir şekilde uzaklaşmasını sağlamaktır. Tablo 2'de görüldüğü gibi tabanda yukarı doğru 4 farklı seviyede ölçüm yapılmış ve ölçümlerde yukarı doğru bağıl nem yüzdesinin azaldığı görülmüştür. Bu durum duvarın çoğunlukla nemi alttan aldığını göstermektedir. Örtünün kapatıldı̆̆ 1 5.günde ise nemin altta \%30-40, üstte ise \%20-25 seviyelerine çekildiği anlaşılmaktadır (Tablo 2).

$X R D: 30 \mathrm{~mA}$ ve $30 \mathrm{Kv}$ ölçüm koşullarında kobalt (Co) anot kullanılarak yapılmıştır. Ögütülmüş R1 ve R3 sıva örneklerinin XRD ölçümleri Co anotta alınmış ve bakır $(\mathrm{Cu})$ 'a dönüştürülerek Amerikan Standart Test Malzeme (ASTM) kartları kullanılarak yorumlanmıştır. Ögütülmüş sıva örneklerinden yapılan XRD ölçümlerinde kalsit mineralinin varlığı tespit edilmiştir. Sıva örneklerinin yüzeyinde gözlenen tuzlanmaya öğütülen örnekte oransal olarak az bulunabileceği nedeniyle XRD difraktogramında rastlanmamıştır (Şekil 4). 


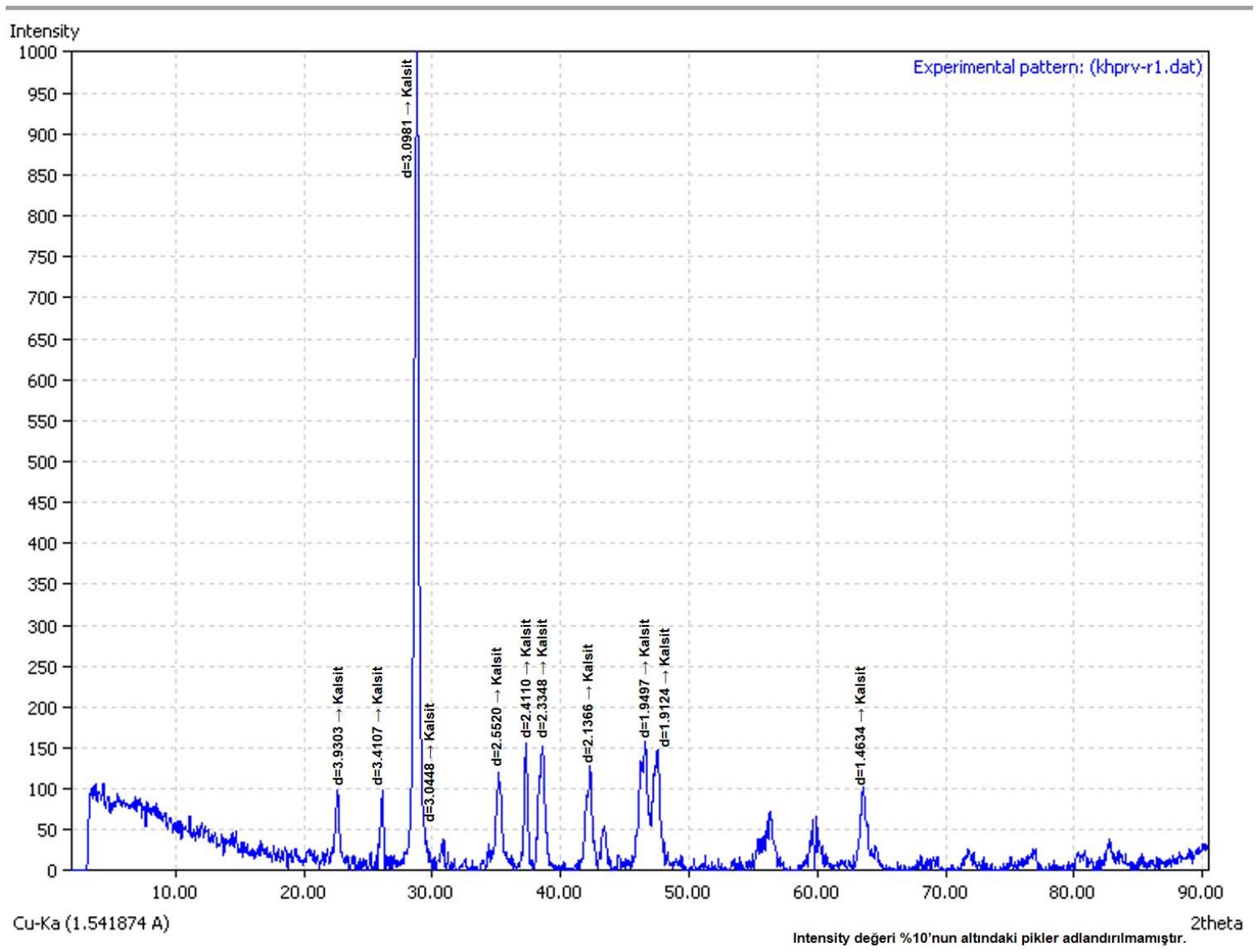

Şekil 4: Sıva örneklerinin temsili X-Işınları difraksiyonu, örnek No: KHPrv-R1 (K. Deniz, Y. K. Kadığlu).

$X R F: \mathrm{M} 1, \mathrm{M} 2, \mathrm{M} 3, \mathrm{R} 2 \mathrm{a}, \mathrm{R} 2 \mathrm{~b}$ ve R4 harç/sıva numunelerinden ölçümler için toz-peletler hazırlanmıştır (Inal vd., 2009, s. 46; Zhan, 2005, s. 207). Bu doğrultuda, benzer ya da farklı kimyasal içerikte oluşlarına göre benzerlikleri veya farklılıkları tespit edilmeye çalışılmıştır. Örnekler ana element içerikleri $(>\% 1)^{7}$ açısından değerlendirilmiştir. Örneklerin XRF analizi sonuçları, ince-kesit petrografiyi destekler niteliktedir (Tablo 3).

Tablo 3: Harç ve sıva numunelerinin XRF sonuçları (M. Eroğlu).

\begin{tabular}{lllllll} 
Element & $\mathbf{M 1}$ & $\mathbf{M 2}$ & $\mathbf{M 3}$ & $\mathbf{R 2 a}$ & $\mathbf{R 2 b}$ & $\mathbf{R 4}$ \\
\hline $\mathrm{Na}_{2} \mathrm{O}$ & 1,021 & 1,127 & 0,928 & 0,765 & 0,679 & 0,248 \\
$\mathrm{MgO}$ & 1,505 & 1,797 & 1,466 & 0,8559 & 0,8775 & 0,3082 \\
$\mathrm{Al}_{2} \mathrm{O}_{3}$ & 3,888 & 4,445 & 3,308 & 1,411 & 1,912 & 1,378 \\
$\mathrm{SiO}_{2}$ & 31,35 & 33,57 & 26,54 & 9,461 & 13,24 & 9,032 \\
$\mathrm{P}_{2} \mathrm{O}_{5}$ & 0,1927 & 0,1553 & 0,1542 & 0,2887 & 0,3031 & 0,1755 \\
$\mathrm{SO}_{3}$ & 0,0624 & 0,0367 & 0,1051 & 0,4568 & 0,2828 & 0,1451 \\
$\mathrm{Cl}$ & 0,0010 & 0,0004 & 0,0015 & 0,0035 & 0,0019 & 0,0096 \\
$\mathrm{~K} 2 \mathrm{O}$ & 0,608 & 0,6173 & 0,4881 & 0,1547 & 0,2233 & 0,0726 \\
$\mathrm{CaO}$ & 36,15 & 32,6 & 36,22 & 47,47 & 43,72 & 50,1 \\
$\mathrm{TiO}_{2}$ & 0,4407 & 0,4983 & 0,3875 & 0,1591 & 0,1867 & 0,116 \\
$\mathrm{~V}_{2} \mathrm{O}_{5}$ & 0,0166 & 0,01655 & 0,01408 & 0,00474 & 0,00519 & 0,00305 \\
$\mathrm{Cr}_{2} \mathrm{O}_{3}$ & 0,02254 & 0,02674 & 0,03052 & 0,00417 & 0,00816 & 0,00448 \\
$\mathrm{MnO}$ & 0,1079 & 0,1304 & 0,1243 & 0,0626 & 0,07412 & 0,02438 \\
$\mathrm{Fe}_{2} \mathrm{O}_{3}$ & 3,53 & 3,939 & 3,01 & 1,181 & 1,292 & 0,8534 \\
\hline
\end{tabular}

${ }^{7} \mathrm{SiO}_{2}, \mathrm{CaO}+\mathrm{MgO}$ ve $\mathrm{Al}_{2} \mathrm{O}_{3}+\mathrm{Fe}_{2} \mathrm{O}_{3}$ değerleri ile üçgen diagram oluşturulmuştur. 


\begin{tabular}{lllllll}
\hline $\begin{array}{l}\text { Kizdirma } \\
\text { kayb1 }\end{array}$ & 79,1 & 79,18 & 72,95 & 62,43 & 62,96 & 62,5 \\
\hline
\end{tabular}

Harç grubu örnekleri ile sıva grubu örneklerinin farklı değerlere sahip olduğu tespit edilmiştir. Buna göre moloz dolgu harçları kendi içlerinde benzer özellik gösterirken sıva örnekleri de kendi içlerinde benzerlik göstermektedir. Bu sonuçlar da petrografik analiz sonuçları ile uyumludur.

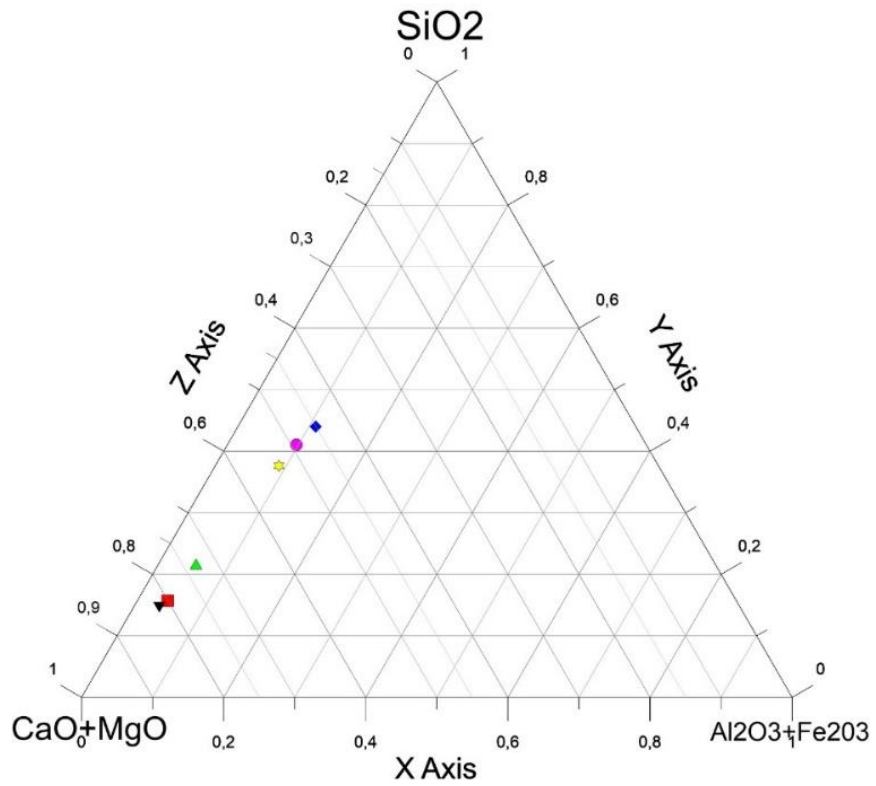

Şekil 5: Harç ve sıva örneklerinin üçgen diyagramındaki $\left(\mathrm{CaO}+\mathrm{MgO}-\mathrm{SiO}_{2}-\mathrm{Al}_{2} \mathrm{O}_{3}+\mathrm{Fe}_{2} \mathrm{O}_{3}\right)$ konumları. Siyah: R4, kırmızı: R2a, yeşil: R2b, sar1: M3, mor: M1, mavi: M2 (M. Eroğlu).

Harç ve sıvaların kimyasal bileşim özellikleri ile elde edilen çimentolanma indeks verileri yardımı ile değerlendirilmiştir (Boynton, 1980) ${ }^{8}$. Buna göre CI değerlerine göre bakıldığında moloz dolgu harçları doğal çimento (DÇ/Ç); sıva örnekleri de ortalama hidrolik kireç (OHK) ve hidrolik kireç (HK) olarak gruplandırılmıştır ${ }^{9}$ (Şekil 5 ve Tablo 4).

\footnotetext{
${ }^{8}$ Cementation Index (CI); asitte çözünen kısmın bazlarda çözünen kısma oranıdır. Indeks değerleri $\mathrm{Cl}=\frac{1.1 \mathrm{Al}_{2} \mathrm{O}_{3}+0.7 \mathrm{Fe}_{2} \mathrm{O}_{3}+2.8 \mathrm{SiO}_{2}}{\mathrm{CaO}+1.4 \mathrm{MgO}}$ formülü ile hesaplanmıștır.
}

${ }^{9}$ Sillyon antik kenti roma hamam yapısında yapılan arkeometrik analizlere göre buradaki yapı işlevsel olarak farklı olması rağmen dönemin harçları hakkında ipucu vermektedir. Harç örneklerinde $\mathrm{CaO}$ içeriği ortalama \% $27.6 \mathrm{Al}_{2} \mathrm{O}_{3}$ içeriği ortalama \% 3.002, $\mathrm{Fe}_{2} \mathrm{O}_{3}$ içeriği ortalama \%0 2,9 ve $\mathrm{SiO}_{2}$ içeriği ortalama \%28,3 değerleri belirlenmiştir. Harç örnekleri kimyasal bileşim özellikleri ile elde edilen Cementation Index verilerine göre kireç türü olarak doğal çimento / çimento katsayısında veriler sunmaktadır (Eroğlu vd. 2020, s.270). 
Tablo 4: Harç ve sıva örneklerinin hesaplanan çimentolanma indeks değerleri ile referans indeks değerleri (Boynton, 1980, s. 275).

\begin{tabular}{|c|c|c|c|}
\hline Element & & \multicolumn{2}{|c|}{ Kireç Türü } \\
\hline KHPrv-M1 & & \multicolumn{2}{|c|}{$\mathrm{DÇ/Ç}$} \\
\hline KHPrv-M2 & & \multicolumn{2}{|c|}{$\mathrm{DÇ/Ç}$} \\
\hline KHPrv-R2a & & \multicolumn{2}{|c|}{ OHK } \\
\hline KHPrv-R2b & & \multicolumn{2}{|c|}{ HK } \\
\hline KHPrv-R4 & & \multicolumn{2}{|c|}{ OHK } \\
\hline KHPrv-M3 & & \multicolumn{2}{|c|}{$\mathrm{DÇ/Ç}$} \\
\hline Lime Type & CI & Kireç Türü & CI \\
\hline Fat Lime & $<0,30$ & Yağlı Kireç & YK \\
\hline Weakly hydraulic Lime & $0,30-0,50$ & Zayıf Hidrolik Kireç & ZHK \\
\hline Moderately hydraulic Lime & $0,51-0,70$ & Ortalama Hidrolik Kireç & OHK \\
\hline Eminently hydraulic Lime & $0,71-1,10$ & Hidrolik Kireç & HK \\
\hline Natural Cements & $1,11-1,70$ & Doğal Çimento & DÇ \\
\hline Cement/Natural Cements & $1,70<$ & Doğal Çimento/Çimento & $\mathrm{DÇ/Ç}$ \\
\hline
\end{tabular}

Ince Kesit-Petrografi: Harç ve sıva örneklerinin ince kesitleri hazırlanarak optik mikroskopta incelenmiștir. R1，R2a，R3，R4 ve M3 harç/s1va numunelerinin ince kesitleri; örneklerde dıştan içe doğru tüm tabakaları gösterecek şekilde doğrudan hazırlanmıştır. Fotoğraflamalar mikroskoba bağl1 Leica DFC280 dijital kamerayla, değerlendirmeler de Leica Qwin Digital Imaging Programı kullanılarak yapılmıştır. M3 harç örneği \%75 agrega \%25 bağlayıcı içermektedir. Agregalar yaklaşık olarak $4 \mathrm{~mm}$. ve daha küçük boyutlarda ve bazalt, tüf gibi volkanik ve mermer, kuvarsit gibi metamorfik kaya parçaları ile birlikte kuvars, çört ve radiolarya içermektedir. Ayrıca $2 \mathrm{~mm}$. ve daha küçük ebatlarda tuğla kırı̆̆ı parçaları da bulunmaktadır. Sıva örneklerinin iki grup olduğu, \%40 agrega \%60 bağlayıcı (R1, R2a, R3) ile \%35 agrega \%65 bağlayıcı içerdiği (R4) görülmektedir. R1, R2a ve R3 sıva numunelerinin agregaları kuvars, çört, plijoklaz, kalsit minerallerini içermekte ve yaklaşık olarak $2 \mathrm{~mm}$. ve daha küçük boyutlara sahiptir. R4 örneğinde ise bazalt, tüf gibi volkanik kaya parçaları birlikte; kuvars, çört mineralleri ile $2 \mathrm{~mm}$. ve daha küçük ebatlarda tuğla kırığı parçaları bulunmaktadır ${ }^{10}$. Yanı sıra, tüm sıvalarda saman olabileceği düşünülen kıtık kullanımına da rastlanmaktadır (Resim 5 ve Tablo $5)$.

\footnotetext{
${ }^{10}$ Tuğla kırıklı harç farklı bölgelerde farklı isimlerle adlandırılmaktadır. Pembemsi tuğla kırıklı kireç harcı cocciopesto olarak Güney Avrupa'da isimlendirilirken yüksek nem ile ilişkili Venedik'te Roma döneminden beri kullanılmakta ve terrazzetto olarak adlandırılmaktadır. Türkiye'de horasan, Arapça'da homra ve Roma döneminde cocciopesto ve Hindistan'da surkhi olarak isimlendirilen tuğla kırıklı harçlar karışıma hidroliklik kazandırmış olmalıdır. Tuğla kırıklı harç ve sıvalar sulu ortamlarda donabildiği için su yapıları, köprüler ve hamamlar bu harç ile yapılmaktaydı (Elsen, 2006, s. 1417; Böke vd., 2006, s. 1115).
} 

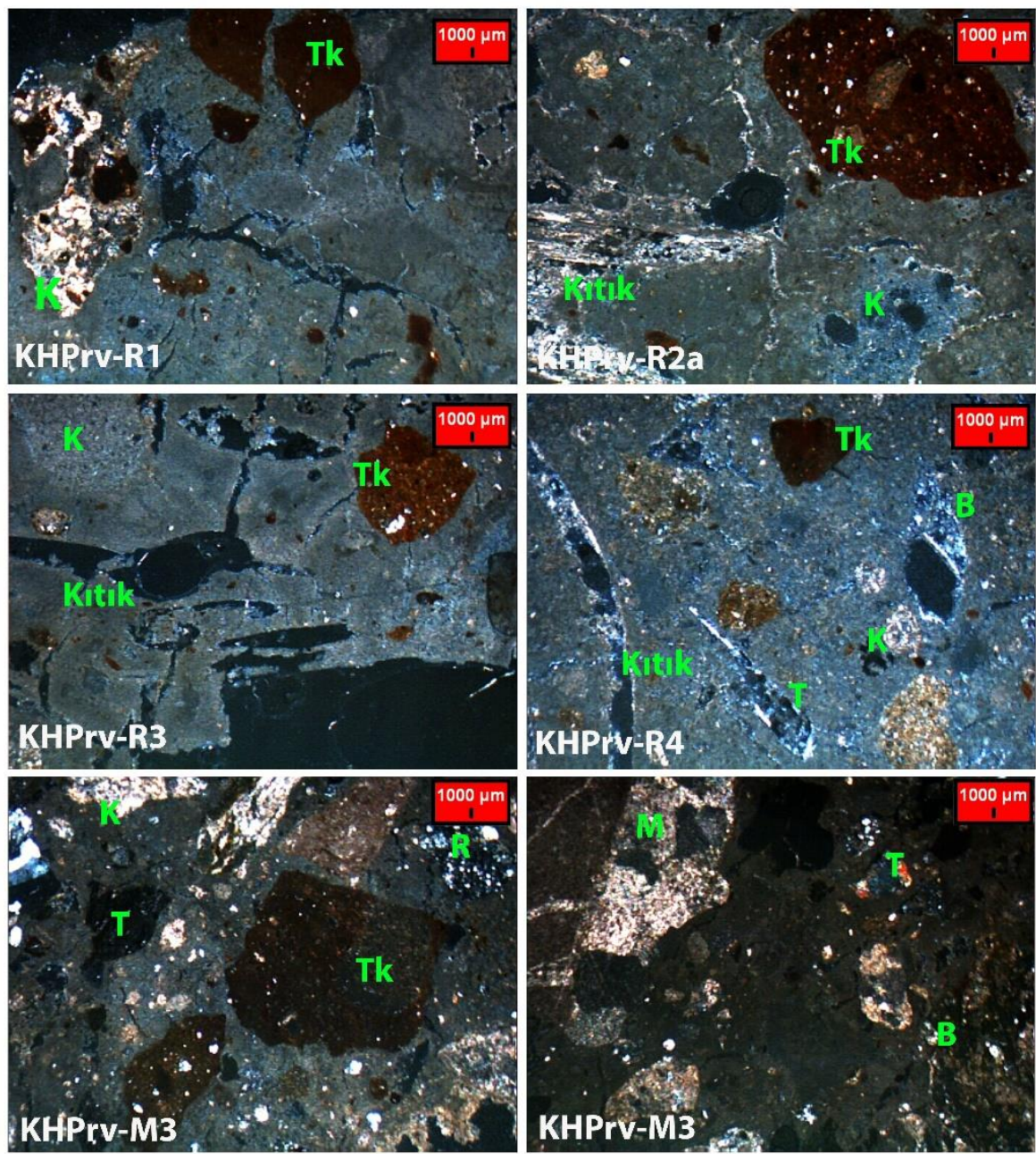

Resim 5: Re, R2a, R3, R4 ve M3 sıva ve harç numuneleri ince-kesitlerinin mikroskop görüntüleri (Y. K. Kadıoğlu, K. Deniz, M. Eroğlu). 


\begin{tabular}{|c|c|c|c|c|c|}
\hline $\begin{array}{l}\text { Tablo 5: H } \\
\text { Siva } \\
\text { Örnekleri }\end{array}$ & $\begin{array}{l}\text { rç ve s } \\
\text { B } \\
(\%)\end{array}$ & $\begin{array}{c}\text { alar11 } \\
\text { A } \\
(\%)\end{array}$ & $\begin{array}{l}\text {-kesit petrografi sonuçları (Y. } \\
\text { Kayaç ve Mineraller }\end{array}$ & $\begin{array}{c}\text { Kadioğlu, K. Deniz, M. } \\
\text { TK }\end{array}$ & $\begin{array}{l}\text { oğlu). } \\
\text { Kittk }\end{array}$ \\
\hline KHPrv-R1 & 60 & 40 & $\begin{array}{c}(\mathrm{Q}, \mathrm{Pl}, \mathrm{Op}, \mathrm{C}, \mathrm{K})^{*} \\
\text { (Agrega yaklaşı 2mm ve daha } \\
\text { küçük) }\end{array}$ & $\begin{array}{c}\% 5,5 \\
\text { (yaklaşık 2mm ve daha } \\
\text { küçük) }\end{array}$ & $\% 2,5$ \\
\hline KHPrv-R2a & 60 & 40 & $\begin{array}{c}(\mathrm{Q}, \mathrm{Pl}, \mathrm{Op}, \mathrm{C}, \mathrm{K})^{*} \\
\text { (Agrega yaklaşı } 2 \mathrm{~mm} \text { ve daha } \\
\text { küçük) }\end{array}$ & $\begin{array}{c}\% 5,5 \\
\text { (yaklaşık } 2 \mathrm{~mm} \text { ve daha } \\
\text { küçük) }\end{array}$ & $\% 2,5$ \\
\hline KHPrv-R3 & 60 & 40 & $\begin{array}{c}(\mathrm{Q}, \mathrm{Pl}, \mathrm{Op}, \mathrm{C}, \mathrm{K})^{*} \\
\text { (Agrega yaklaşık } 2 \mathrm{~mm} \text { ve daha } \\
\text { küçük) }\end{array}$ & $\begin{array}{c}\% 5,5 \\
\text { (yaklaşık } 2 \mathrm{~mm} \text { ve daha } \\
\text { küçük) }\end{array}$ & $\% 2,5$ \\
\hline KHPrv-R4 & 65 & 35 & $\begin{array}{c}(\mathrm{Q}, \mathrm{Pl}, \mathrm{Op}, \mathrm{B} . \mathrm{Tf}, \mathrm{K})^{*} \\
\text { (Agrega yaklaşı } 2 \mathrm{~mm} \text { ve daha } \\
\text { küçük) }\end{array}$ & $\begin{array}{c}\% 7 \\
\text { (yaklaşık } 2 \mathrm{~mm} \text { ve daha } \\
\text { küçük) }\end{array}$ & $\% 12,5$ \\
\hline KHPrv-M3 & 25 & 75 & $\begin{array}{c}(\mathrm{Q}, \mathrm{Pl}, \mathrm{Op}, \mathrm{B}, \mathrm{M}, \mathrm{R}, \mathrm{Kst})^{*} \\
\text { (Agrega yaklaş1k 4mm ve daha } \\
\text { küçük) }\end{array}$ & $\begin{array}{c}\text { (yaklaşı } 2 \mathrm{~mm} \text { ve daha } \\
\text { küçük) }\end{array}$ & Yok \\
\hline
\end{tabular}

Pigmentler (CRS): Pigmentlerde rengi elde etmede kullanılan malzemeyi tespit etmeye yönelik nokta analizi şeklinde $633 \mathrm{~nm}$ lazer kullanılarak $2 \mathrm{~cm}^{-1}$ çözünürlük ve $100-1200 \mathrm{~cm}^{-1}$ aralığında ölçülmüştür (Deniz, 2021; Deniz \& Kadıŏglu, 2021). Farklı renklerdeki P1, P2, P3, P4 ve P6 (siyah, kırmızı, sarı ve yeşil) numunelerinin pigmentlerinde rengin kaynağını tespit etmeye yönelik KRS analizleri yapılmıştır. Yapılan analizlere göre siyah renk karbon buna karşılık kırmızı, sarı ve yeşil renkler ise siderit kullanılarak elde edilmiştir. Siderit mineralinin $1089 \mathrm{ve} 283 \mathrm{~cm}^{-1}$ de Raman kaymaları mevcuttur. XRD ölçümlerinde siderit mineralinin tespit edilememesi ögütülen örnekte boyanın az oluşu ya da hiç olmayışından kaynaklanmaktadır. KRS ölçümleri duvar resminden alınmış sıva örneğinin üzerindeki boya örneğine hiçbir şekilde müdahale edilmeden uygulanmıştır. $\mathrm{Bu}$ nedenle XRD verisi genel ve baskın durumu yansıtırken KRS verisi özel ve belirli bir alanın bileşimini yansıtmaktadır (Şekil 4 ve 6). 


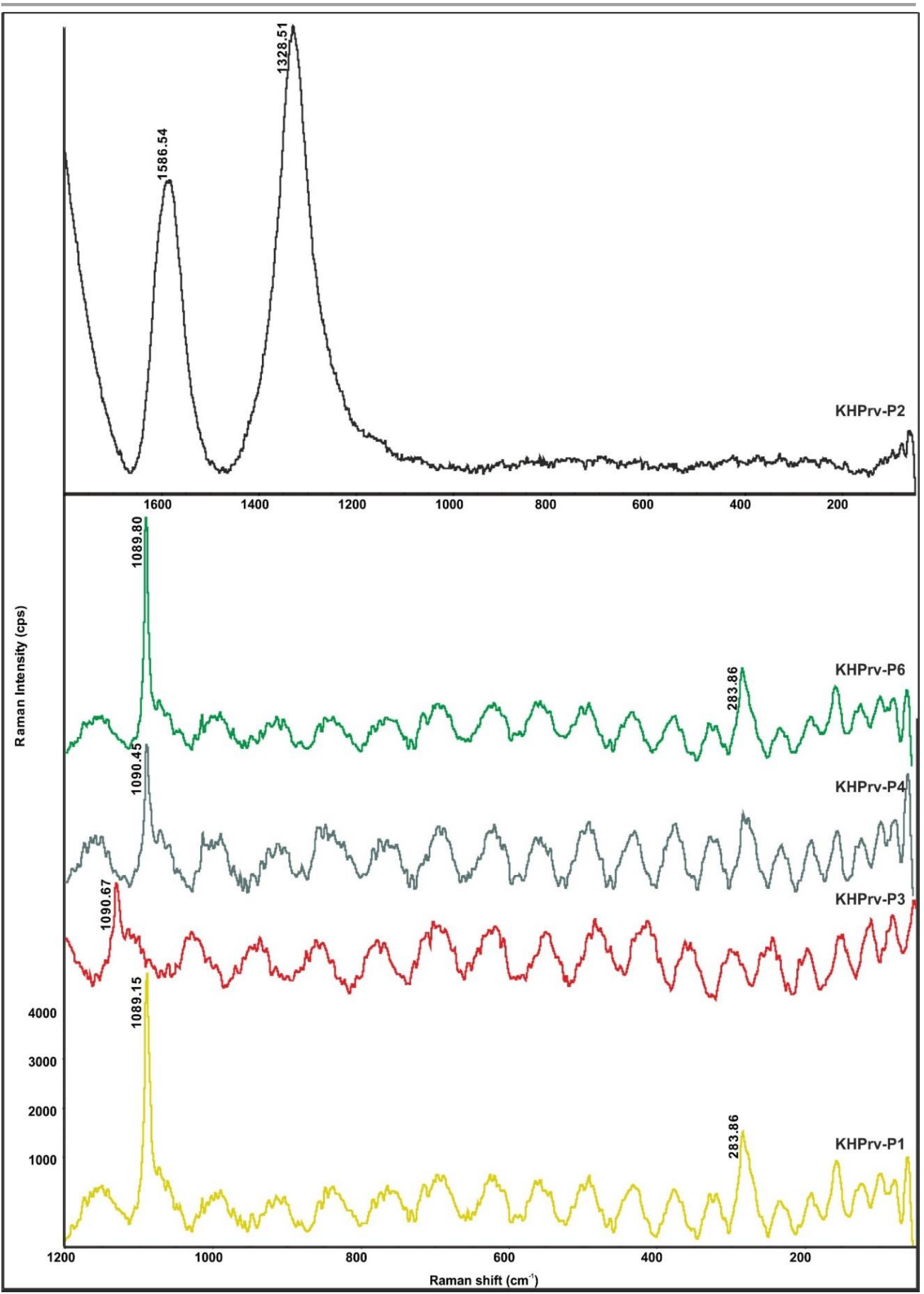

Şekil 6: P1, P2, P3, P4 ve P6 numunelerinin pigment örneklerinin karşılaştırmalı Raman spektrumları (K. Deniz, Y. K. Kadıŏlu). 


\section{Değerlendirme}

Hadrianoupolis Antik Kenti Geç Roma Villası, Oda-3'te gerçekleştirilen ve 5 günü kapsayan ön inceleme çalışmaları malzeme, teknik ve koruma müdahaleleri hakkında bazı ön bilgiler sunmuştur.

\section{Yapım teknikleri:}

OM görüntüleri duvar resimlerinin yapılış teknikleri ile ilgili bizlere bazı ipuçları vermektedir. Görüntülerde ince sıva tabakası ile resim tabakasının aynı olduğu ve ayrıca bir tabaka olarak boya tabakasının olmadığı görülmektedir. IR spektrumlarında restorasyon materyalleri haricinde bir bağlayıcı maddenin tespit edilememesi resimlerin yaş sıva üzerine (fresko) yapılmış olabileceğini destekler niteliktedir. Bunların haricinde, çıplak göz ile yapılan gözlemlerde, Oda3'ün duvarlarında yer alan resimlerde yapılış tekniklerine (kazıma, kömür tozu, sinopia çizimi, kurşun kalem izi v.b.) ait herhangi başka bir ize rastlanmamıştır. Ancak resimlerin yapıldığı sırada damladığı düşünülen boya lekeleri tespit edilmiştir (Resim 6). Bunlar, sanatçının uygulama sırasındaki kusurları olarak adlandırılabilir.

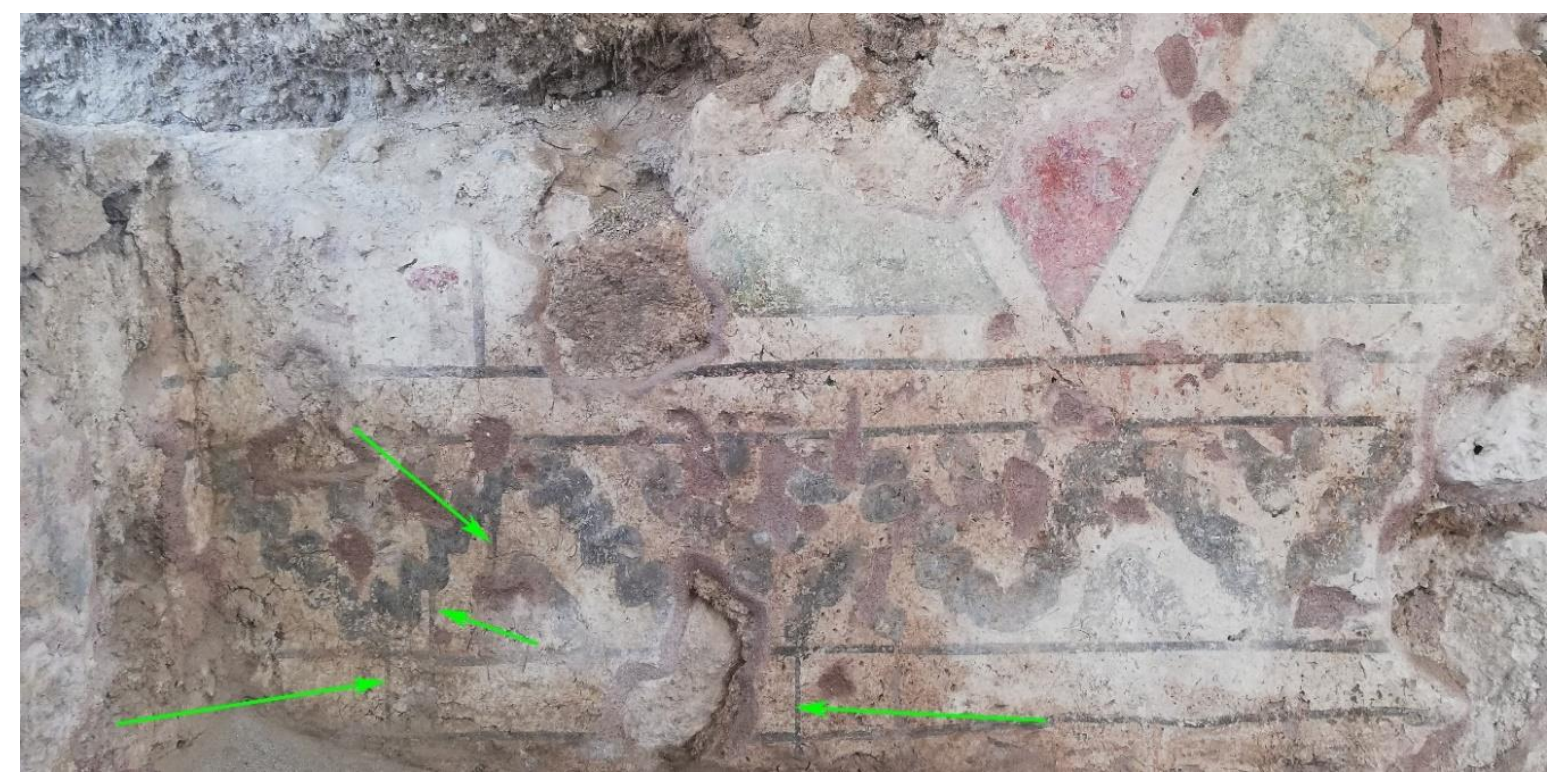

Resim 6: Geç Roma Villası duvar resimlerinden bazı detaylar; uygulama sırasındaki kusurlar, boya damlamaları (E. Yetiş).

UV-ampul incelemelerinde, fresko tekniğinde yapıldığı düşünülen resimler üzerinde farklı dönem onarım katmanı olabilecek rötuş (reintegration) veya üzerine boyama (overpainting) izlerine rastlanmamıştır ${ }^{11}$.

Fresko yapımında sanatçının yaş sıvayı uyguladığında kuruyana dek uyguladığı ve günlük iş anlamına gelen giornata izlerini (Mora vd., 1984, s.10-11) tespit etmenin güçlügü resmin üzerindeki beyaz tabakadan kaynaklanmaktadır.

XRF ölçümleri ve ince-kesit petrografi sonuçlarına göre; moloz dolgu ve derz harçlarında doğal çimento indeks değerlerinde 3/1 (Agrega/Bağlayıcı) oranlarında karışımlar kullanılmıştır. Kaba siva ve resim siva katmanı olarak adlandırılabilecek numunelerde ise ortalama hidrolik (OHK) ve hidrolik (HK) değerlerinde ve 2/3 (Agrega/Bağlayıcı) oranlarında kireç bağlayıcının olduğu karışımlar tercih edilmiştir (Tablo 4). Bununla birlikte sıva ve harçların mukavemeti için kıtık katkısı olduğu görülmektedir. Ayrıca yüzeye yakın kısımdaki üst sıva numunesi olan R2a'nın

${ }^{11}$ Reintegration ve overpainting ile ilgili bakınız Yetiş vd. (2021, s.17-36). 
ortalama hidrolik, aynı yerden ve daha derinden alınan R2b sıva numunesinin ise hidrolik harçlar indeks değerlerine dahil olduğu görülmektedir. Bu durum ince ve kaba olarak 2 tabaka sıvanın kullanıldığını ve bu sıvaların farklı hidrolik değerlerinde olduğunu gösterir. (Şekil 5, Tablo 4 ve Tablo 5). Bununla birlikte son katman sıvası olduğu düşünülen R2a sıvası ile R4 sıvasının hidrolik değerleri hemen hemen aynıdır. Genel olarak alt katman sıvanın son katman sıvaya göre hidrolik özelliği yüksek görünmektedir ve sıvaların temsili olarak görünümü tabaka ave tabaka $b$ olarak Resim 2'de gösterilmiştir. Petrografideki B/A oranlarına bakıldığında (Tablo 5) ise bağlayıcı oranının yüksekliği ile R1, R3 ve R4 sivalarının R2a sıvası gibi son katman sıvası olduğu düşünülebilir. R4 kıtık oranının yüksekliği ile diğerlerinden biraz farklıdır.

Sorunlar:

2007'den beri yapılan bakım çalışmaları sayesinde, resimlerin sıva arkası ve yüzeyi oldukça sağlam görünmektedir. Göze çarpan önemli iki biri resim yüzeyindeki beyaz tabaka, diğeri ise bitki gelişimidir. Bitki gelişimi henüz resim yüzeyinde ve sıva katmanlarında çatlama, dağılma v.b. bozulmalara sebep olmamıştır. XRD ölçümlerine göre farklı iki yerden alınan numunelerde kalsit oluşumu dışında kristal yapı bulunamamıştır. $\mathrm{Bu}$ durum yüzeydeki beyaz tabakanın $\mathrm{CaCO}_{3}$ oluşumu ihtimalini güçlendirmektedir (Mora vd., 1984, s. 180). Aksine P1 ve P4 numunelerinin IR spektrumlarında sülfat tuzları $(\mathrm{S}-\mathrm{O})$ ve hidrat suyu $(-\mathrm{OH})$ varlı̆̆ına rastlanmıştır. Bu durum yer yer sülfat yapılarına ve buna bağlı hidrat suyu oluşumlarına işaret edebilir. Sülfat tuzlarının oluşumu nem kaynaklı olarak mevcut (harç-sıva) gözenekli malzemenin içerisinde hareket eden sudan dolayı malzeme yapısının ayrışması ile gerçekleşebilir. Malzeme yapısında zaten mevcut olan kalsiyum, sodyum, potasyum ve magnezyumun su içerisinde ayrışması ve sülfat tuzları (S-O) yeni bir yap1 oluşturduğu söylenebilir (Mora vd., 1984, s.181). Ayrıca nemli ortamda kullanılan sağlamlaştırma harçları da sülfat tuzlarını oluşturabilmektedir.

Toprak altından çıkarıldığı 2007 yılından beri birkaç sefer (yaz aylarına denk gelen kazı dönemlerinde) bakım çalışmaları yapılan resimlerin koruyucu örtü altından çıkarıldığında oldukça yüksek bağıl neme sahip olduğu tahmin edilmektedir. Özellikle ön çalışmalar sırasında hazırlanan 5 günlük bağıl nem tablosu bunu doğrulamaktadır. Arkeolojik malzemelerin müdahale öncesinde nem koşullarının kontrol edilmesi ve sıvalardaki nemin normal (\%15 ve altı) düzeye çekilmesi gerekir (Mora vd., 1984, s. 166). Bu işlemin kontrollü ve yavaş yapılması gerekir. Ancak nem kontrolü yapılmadan uygulanan bir sağlamlaştırma müdahalesi (hidrolik özellikli enjeksiyon harc1 gibi) yüksek nemli sıva ve duvara yayılacaktır. Bu durum özellikle sslak resim yüzeyine nüfuz eden $\mathrm{Ca}(\mathrm{OH})_{2}$ 'nin $\mathrm{CaCO}_{3}$ 'e dönüşmesine ve kir tabakası ile birlikte yüzeyde sabitlenmeye sebep olacaktır. Beyaz tabakanın oluşum sebebinin kalkerleşme $\left(\mathrm{CaCO}_{3}\right)$ olma ihtimali yüksektir.

\section{Müdahale Önerileri:}

- Önleyici koruma çerçevesinde kullanılan jeotekstil örtünün ani nem değişimlerini engellediği, ancak yüksek nem oluşumunu engellemediği anlaşılmaktadır. $\mathrm{Bu}$ sorunun çözülebilmesi için, ek olarak resimlerin bulunduğu odaların üzerinin geçici olarak ahşap çatı ile kapatılması (Neguer \& Alef, 2014, s. 23; Eryurt \& Özdemir, 2020, s. 106) ve odaların etrafindaki drenajın sağlanması gerekmektedir.

- Analitik ölçüm ve görüntülerde fresko tekniğinde yapıldığı düşünülen resimlerde bağlayıcı maddenin (yumurta, kazein, hayvan tutkalı v.b.) kullanılmamas1 restorasyon müdahalelerin su ve diğer çözücülerin (etanol, aseton gibi) kullanımında avantaj sağlamaktadır. Ayrıca siderit kaynaklı $\left(\mathrm{FeCO}_{3}\right)$ pigmentlerin ${ }^{12}$ kullanılması da su ile müdahalelerde riski bir durum oluşturmayacaktır.

\footnotetext{
12 Özellikle, yeşil ve mavi renkleri veren azurit ve malahit gibi bakır $(\mathrm{Cu})$ kaynaklı pigmentlerin suyun varlığında bakır sülfitlere (Cu2 $\mathrm{S}, \mathrm{CuS})$ dönüşebilecekleri bilinmektedir (Mora vd., 1984, s.66). Bu durum renk değişimine neden olacaktır.
} 
- Kalker/kir tabakası olduğu düşünülen yüzey beyazlığı su ve etanol karışımı (1/1) ile $\mathrm{e}^{13}$ nemlendirilerek bistüri ile kazıma yöntemi kullanılarak temizliği yapılabilir. Kalker $\left(\mathrm{CaCO}_{3}\right)$ suda çözünebilen bir madde olmadığından amonyum karbonat-demineralize su paketlemesi faydalı olmayabilir. Kalsit'in çözünebildiği asidik çözeltiler veya şelatlaştırıcı malzemeler kullanımı uygun olabilir ancak kontrollü olunması gerekmektedir. Özellikle şelatlaştırıcı maddelerin (EDTA, HEDTA, Tetrasodyum EDTA, DTPA gibi) yüzeyde kalıntı bırakmaması için çok iyi arındırılmaları gerekir (Burgess, 1991, s.36-44).

- Moloz dolgu/derzlerde 3/1 (A/B) ve kaba/ince sıvalarda 2/3 (A/B) karışımlara istinaden bordür ve kayıp kısımların 2/1 (A/B) oranlarda olması uygun olabilir. Ayrıca sıvaların hidrolik özellikleri dolayısı ile restorasyon için kullanılacak kirecin de hidrolik özellikte olması tavsiye edilmektedir. Ayrıca bölgedeki dere kumunun petrografik olarak araştırılması ve benzer kumun restorasyon sıvalarında kullanılması önerilmektedir.

- Bitki gelişimi için uygulanacak tedaviye nem sorunu çözüldükten sonra başlanmalıdır. Öncelikle bitkiler koparılmadan temizlenmeli ve herbisit (herbicide) ${ }^{14}$ özellikli bir malzeme uygulaması ile gelişimlerinin engellenmeye çalışılmalıdır.

\section{Malzeme ve teknik ile ilgili yapılabilecek diğer araştırmalar:}

- OM görüntüleri ve IR spektrumlarını desteklemek amacı ile Taramalı Elektron Mikroskobu (SEM) EDS (Energy Dispersive Spectroscopy) dedektörü ile Ca (kalsiyum) elementel haritalama yapılabilir. $\mathrm{Bu}$ analiz yaş sıvanın kuruma aşamasında $\mathrm{Ca}$ hareketini görmemizi sağlayacak, resimlerin fresko olduğunu ve hangi kalitede bir fresko tekniği olduğunu (buon fresco, mezzo fresco) kanitlayacaktır.

- Resimleri yapan sanatçının günlük yaptığı sıva alanlarını (giornata) resim yüzeyindeki beyaz tabakanın temizlenmesinden sonra görebilmek (şayet varsa) daha kolay olacaktır. Ayrıca giornata izlerinin olmaması sanatçının resmi tek seferde hazırladığı sıva üzerine yapmış olduğunu gösterebilir. Dikkatli ve kontrollü bir temizlik işlemi yapılırsa eğer varsa uygulama izlerini (kömür tozu, kazıma, kurşun kalem gibi) de ortaya çıkarmak mümkün olabilir.

- Yüzey temizlik çalışmalarından sonra yapılacak UV-ampül ile incelemeler eğer varsa rötuş ve üzerine boyamalar daha net görüneceği için tekrar yapılması gerekir.

- XRF sonuçlarına göre bazı dolgu harçlarının indeks değerleri (doğal çimento olarak) oldukça yüksek ölçülmüş̧ür. İleriki bilimsel çalışmalarda numune sayısı arttırılarak ve antik kentin diğer sıva özellikleri ile karşılaştırılarak detaylı olarak araştırılması gerekir.

- R2b daha az örnek alınabilmiştir. Bu nedenle petrografik analiz yapılamamış sadece XRF analizi yapılmıştır. XRF sonuçları da R2a ve R2b sıvalarının farklı olduğunu göstermiş, ancak ileride yapılacak çalışmalarda daha fazla örnek alınarak ince ve kaba sıva özellikleri değerlendirilmelidir.

- Harç ve sıva örneklerde bazı agregaların içinde volkanik kayaçlardan bazalt, tüf ile sedimanter kayaçlardan radiolarit tespit edilmiştir. Bu durum kazı bölgesinin çevresinde volkanik oluşumlar ve/veya Ofiyolit ile ilişkili olabilitr ${ }^{15}$. Daha sonraki çalışmalarda da bu bölgelerden alınacak örneklerle de karşılaştırılmalıdır.

\footnotetext{
${ }^{13}$ Kalker $\left(\mathrm{CaCO}_{3}\right)$ su veya etanolde pratikte çözünebilir bir malzeme değildir. Ancak asitlerde çözünebilir (National Library of Medicine, t.y.).

${ }^{14}$ Herbisitler ile ilgili daha detaylı bilgi için bakınız; Andrew \& Reade (2011).

${ }^{15}$ Ofiyolitler okyanusal oluşum ile ilişkili olup ofiyolit serisi ve ofiyolit melanjdan olarak iki gruba ayrılmaktadır. Buna göre ofiyolit seri taban metamorfitleri, üst manto peridotitleri (harzburjitler, pirksenit ve gabrolar), ultramafik-mafik kümülartlar ve denizel çökellerle (pelajik kireçtaşı, radiolarit) birlikte bazaltları içerir. Bu oluşumun diğer bir parçası olan Ofiyolit melanj ise, serpantinize harzburjit, gabro, bazalt, diyabaz, granit, çamurtaşı, çört içeren kayaçları kapsamaktadır (Sarıfakılığlu 2017,s 1). Buna göre harç ve sıva örnekleri içersinde bazalt, radiolar ve çamurtaşı içeren kaya parçaları
} 


\section{Sonuç}

Hadrianoupolis Antik Kenti, Geç Roma Villası'nın üç odasında yer alan duvar resimlerinin korunması kapsamında yalnızca Oda-3'teki resimler üzerinde bilimsel ve teknik çalışmalar yapılmıştır. Bu kapsamda ileride yapılacak olan koruma çalışmalarına katkıda bulunacak sonuçlar elde edilmiştir. Ön inceleme çalışmaları özellikle koruma sürecinde uygulanacak müdahalelerin mevcut özgün malzemeye zarar vermemesi ve doğru yöntemlerin seçilmesi konusunda arkeolojik alanlardaki duvar resimleri için hayati bir konudur. Çalışmadaki resimlerin uzun vadede ve kalıcı olarak nem sorunlarının çözüldükten sonra müdahaleye başlanması, uygulanacak yöntem ve malzemenin daha doğru sonuç vermesini sağlayacaktır. Bu durum geçici çatı ve drenaj sorunlarının çözülmesini gerektirmektedir. Kullanılan pigmentler, yüzey kir ve diğer tabakalarının bilinmesi koruma uzmanlarını deneysel uygulamalar ve literatür araştırmaları yolu ile çözüme daha kolay ulaştıracaktır. Sonuç olarak arkeolojik alanlardaki duvar resimlerinin koruma müdahalelerinin bilimsel yöntemler ile yapılabilmesi için ön inceleme çalışmalarının arttırılması önem arz etmektedir.

\section{Kaynakça}

Ajò, D., Casellato, U., Fiorin, E. \& Vigato, P.A. (2004). Ciro Ferri's frescoes: a study of painting materials and technique by SEM-EDS microscopy, X-ray diffraction, micro FT-IR and photoluminescence spectroscopy. Journal of Cultural Heritage, 4(5), 333-348. https://doi:10.1016/j.culher.2004.05.003

Bilginer, E., Bilgiç, T., Duru, M., Ercan, T., Gedik, İ., Günay, Y., Güven, İ.H., Hakyemez, H.Y., Konak, N., Papak, İ., Pehlivan, Ş., Sevin, M., Şenel, M., Tarhan, N., Turhan, N., Türkecan, A., Ulu, Ü., Uğuz, M.F., Yurtsever, A. vd. (2011). 1:1.250.000 ölçekli Türkiye jeoloji haritası. Maden Tetkik ve Arama Genel Müdürlüğü Yayını, Ankara-Türkiye. http://yerbilimleri.mta.gov.tr/anasayfa.aspx

Blackligth Blue (t.y.). Philips lighting. https://www.assets.lighting.philips.com /is/content/PhilipsLighting/fp928011310821-pss-en_us

Boynton, R. S. (1980). Chemistry and technology of lime and limestone (2nd Ed.). John Wiley \& Sons Inc.

Böke, H., Akkurt, S. , İpekoğlu, B. \& Uğurlu, E., (2006). Characteristics of brick used as aggregate in historic brick-lime mortar and plaster. Cement and Concrete Research, 36, 115-1122.

Casadio, F., Giangualano, I. \& Pique, F. (2004). Organic materials in wall paintings: The historical and analytical literature. Studies in Conservation, 49, 63-80.

Cobb, Andrew H., Reade John P. H. (2011). Herbicides and plant physiology. John Wiley \& Sons. ISBN 9781444322491.

Çelikbaş, Ersin \& Ekinci, Sinan (2021). Yeni veriler 1şığında geç Roma konutu (domus) hakkında değerlendirmeler. V. Keleş, E. Çelikbaş, A. Yılmaz (Ed.), Hadrianoupolis Serisi-1, Karabük-Eskipazar Paphlagonia Hadrianoupolis'i, 2010-2014 Kazı Sezonlarl (ss.155160). Bilgin Kültür Sanat Yayınları.

Deniz, K. \& Kadioglu, Y.K. (2021). Geochemistry of salts and the effect of trace elements on human health: Turkey salt resources. International Journal of Environmental Analytical Chemistry. https://doi:10.1080/03067319.2021.1934830

tespit edildiğinde ofiyolit seri ve ofiyolit melanj içeren bölgeler akla gelmekte ve bu oluşumlar ofiyolitlerle ilişki kurmakta önemli ipucudur. Agregada görülen bu kaya parçaları ve mineraller Eskipazar'ın çevresinde çele metaofiyoliti (Sarıfakılığlu 2017,s 20) ile, volkanik oluşumlar ise Eskipazar'ın güney ve güneydoğusundaki kaynaklar ile ilişkili olabilir (Akbaş vd., 2011). 
Deniz, K. (2021). Mica types as indication of magma nature, Central Anatolia, Turkey. Acta Geologica Sinica. https://doi:10.1111/1755-6724.14670

Derrick, M. R., Stulik, D. \& Landry, J. M. (1999). Infrared spectroscopy in conservation science. Getty Conservation Institute.

Elsen, J. (2006). Microscopy of historic mortar. Cement and Concrete Research, 36, 1416-1424.

Eroğlu, M., Yaşar, A., Kadığlu, Y. K. (2020). Sillyon antik kenti Roma hamamı yapısında arkeometrik analizler, Ed. M. Taşkıran. Yüzey Araştırmaları Işı̆̆ı̆nda Sillyon ve Çevresi kitabı içinde (ss. 255-264). Ege Yayınları, ISBN:978-605-7673-48-0

Eryurt, B. Ç. \& Özdemir, S. (2020). Arkeolojik kazı sırasında buluntuların zarar görmesini engellemeye yönelik koruma yaklaşımları. Ed. C. Keskin. 35. Arkeometri Sonuçları Toplantısı. 17-27 Haziran 2021 (ss. 95-110). T.C. Kültür ve Turizm Bakanlığı Yayınları.

Helen Burgess (1991). The use of chelating agents in conservation treatments, The Paper Conservator, 15(1), 36-44, http://doi:10.1080/03094227.1991.9638395

Inal, A., Gunes, A., Pilbeam, D. J., Kadioglu, Y. K. \& Eraslan, F. (2009). Concentrations of essential and nonessential elements in shoots and storage roots of carrot grown in $\mathrm{NaCl}$ and $\mathrm{Na}_{2} \mathrm{SO}_{4}$ Salinity. X-Ray Spectrometry, 38(1), 45-51.

Keleş, V- Çelikbaş, E.-Yılmaz, A. (2011). Hadrianoupolis 2010 yılı çalısmaları (ilk Sezon), 33.Kazı Sonuçları Toplantısı (ss. 39-53), T.C. Kültür ve Turizm Bakanlığı Yayınları.

Keleş, V. - Çelikbaş, E. (2013) Paphlagonia Hadrianoupolisi'nde bulunmus kapı temalı mezar steli. Turkish Studies, 8(6), 365-376. http://dx.doi.org/10.7827/TurkishStudies.4779

Kılavuz, B. N. \& Çelikbaş, E. (2013). Paphlagonia Hadrianoupolis'i. Tarih Kültür Sanat Araştırmaları Dergisi, 2, 159- 214.

Laflı, E. (2008). Hadrianoupolis-Eskipazar Paphlagonia Hadrianoupolis'i arkeolojik kazıları. 30.Kazı Sonuçları Toplantısı (ss. 399-410), T.C. Kültür ve Turizm Bakanlığı Yayınları.

Laflı, E. (2009). Paphlagonia Hadrianoupolis'i arkeolojik kazıları ve onarım çalısmaları 2008 yılı çalısma raporu. Arkeoloji ve Sanat, 131, 39-62.

Mora, P., Mora, L. \& Philippot, P. (1984). Conservation of wall paintings. Butterworths.

National Library of Medicine (t.y.). Calcium carbonate. National Center for Biotechnology Information carbonate\#section=Melting-Point

https://pubchem.ncbi.nlm.nih.gov/compound/Calcium-

Ndiaye, M., M. Diop \& P. M. Ngom. (2003). Pozzolanic activity of acidic and intermediate volkanic tuffs of Mako Areas (Senegal). Ed. E Yüzer, H. Ergin \& A. Tuğrul. International Symposium on Industrial Minerals and Building Stones, IMBS'2003 (ss. 517-525), İstanbul: Kelebek ve Grafika Grup.

Piovesan, R., Mazzoli C. \& Maritan, L. (2012). Fresco and lime-paint: an experimental study and objective criteria for distinguishing between these painting techniques. Archaeometry, 54(4), 723-736. http://doi: 10.1111/j.1475-4754.2011.00647.x

Poliszuk, A. \& Ybarra, G. (2013). Analysis of cultural heritage materials by infrared spectroscopy. In Daniel Cozzolino (Ed.), Infrared Spectroscopy: Theory, Developments and Applications. Australia: Nova Science Publishers.

Sarıfakılığlu, E., Sevin, M.- Dilek, T. (2017). Türkiye ofiyolitleri. MTA, Özel Yayın Serisi: 35. 
Sarmiento, A., Pérez-Alonso, M., Olivares, M., Castro, K., Martinez- Arkarazo, I., Fernandez, L. A. ve Madariaga, J. M. (2011). Classification and identification of organic binding media in artworks by means of Fourier transform infrared spectroscopy and principal component analysis. Anal Bioanal Chem, 399, 3601-3611. http://doi:10.1007/s00216-011-4677-0

Şimşek, O. (2003). Yapı malzemesi. (2. Baskı). BetaYayınevi.

Vahur, S., Teearu, A. \& Peets, P. (2016). ATR-FT-IR spectral collection of conservation materials in the extended region of 4000-80 cm-1. Anal Bioanal Chem, 408, 3373-3379. http://doi:10.1007/s00216-016-9411-5

Yetiş, Ezgin. (2019). Tarihi duvar resimlerinde kullanılan boya ve bağlayıcılar. Ed. C. Ünal \& C. Gürbıyık. Uluslararası XIX. Ortaçă̆ ve Türk Dönemi Kazıları ve Sanat Tarihi Araştırmaları Sempozyumu (ss. 507-530), Türk Tarih Kurumu Yayınları.

Zadrożna, Irmina, Kasia Połeć-Pawlak, Iwona Głuch, Mohamed A. Ackacha, Mirosław Mojski, Janina Witowska-Jarosz \& Maciej Jarosz. (2003). Old master paintings- a fruitful field of activity for analysts: targets, methods, outlook. Journal of Separation Science, 26, 9961004.

Zhan, X. (2005). Application of polarized edxrf in geochemical sample analysis and comparison with wdxrf. X-Ray Spectrometry, 34(3), 207-212.

\section{Teșekkür:}

Çalışmanın ortaya çıkmasına vesile olan Hadrianoupolis Antik Kenti kazı başkanı Doç. Dr.

Ersin ÇELIKKBAŞ'a, kazı ekibine ve yapılan analizler ile ilgili destekleri için "Kastamonu Üniversitesi Merkezi Araştırma Laboratuvarı Uygulama ve Araştırma Merkezi (MERLAB)" ile "Ankara Üniversitesi Yer Bilimleri Uygulama ve Araştırma Merkezi (YEBİM)"ne teşekkürlerimizi sunarız.

\section{Beyan ve Açıklamalar (Disclosure Statements)}

1. Araştırmacıların katkı oranı beyanı / Contribution rate statement of researchers:

1. Yazar/First author $\% 50$,

2. Yazar/Second author $\% 30$

3. Yazar/Second author $\% 10$

4. Yazar/Second author $\% 10$

2. Yazarlar tarafından herhangi bir çıkar çatışması beyan edilmemiştir (No potential conflict of interest was reported by the authors). 